\title{
WP 08_14
}

\author{
Chih Ming Tan \\ University of North Dakota, USA
}

The Rimini Centre for Economic Analysis (RCEA), Italy

Zhibo Tan

Peking University, China

Xiaobo Zhang

Peking University, China

International Food Policy Research Institute (IFPRI), USA

\section{SINS OF THE FATHER: THE INTERGENERATIONAL LEGACY OF THE 1959-61 GREAT CHINESE F AMINE ON ChILdREN's COGNITIVE DEVELOPMENT}

Copyright belongs to the author. Small sections of the text, not exceeding three paragraphs, can be used provided proper acknowledgement is given.

The Rimini Centre for Economic Analysis (RCEA) was established in March 2007. RCEA is a private, nonprofit organization dedicated to independent research in Applied and Theoretical Economics and related fields. RCEA organizes seminars and workshops, sponsors a general interest journal The Review of Economic Analysis, and organizes a biennial conference: The Rimini Conference in Economics and Finance (RCEF) . The RCEA has a Canadian branch: The Rimini Centre for Economic Analysis in Canada (RCEACanada). Scientific work contributed by the RCEA Scholars is published in the RCEA Working Papers and Professional Report series.

The views expressed in this paper are those of the authors. No responsibility for them should be attributed to the Rimini Centre for Economic Analysis. 


\title{
Sins of the Father: The Intergenerational Legacy of the 1959-61 Great Chinese Famine on Children's Cognitive Development
}

\author{
Chih Ming Tan Zhibo Tan Xiaobo Zhang
}

March 13, 2014

\begin{abstract}
The intergenerational effect of fetal exposure to malnutrition on cognitive ability has rarely been studied for human beings in large part due to lack of data. In this paper, we exploit a natural experiment, the Great Chinese Famine of 1959-61, and employ a novel data set, the China Family Panel Studies (CFPS), to explore the intergenerational legacy of early childhood health shocks on the cognitive abilities of the children of parents born during the famine. We find that daughters born to rural fathers who experienced the famine in early childhood score lower in major tests than sons, whereas children born to female survivors are not affected. By careful elimination of alternative explanations, we conclude that the culling effect on the exposed generation is remarkably efficient at mitigating the intergenerational transmission of any scarring effects from the famine. The uncovered gender-specific effect is almost entirely attributable to son-preference exhibited by rural famine fathers. Our findings suggest that, at least for cognitive abilities, human populations appear to be extremely resilient to shocks, largely shielding their offspring from being seriously damaged.
\end{abstract}

Keywords: Famine; Health; China; Intergenerational Transmission; Epigenetics

JEL Codes: O12, I12, I15, J10, J13

C. M. Tan: Department of Economics, College of Business and Public Administration, University of North Dakota, Gamble Hall, 293 Centennial Drive, Grand Forks, ND 58202-8369, USA. Z. Tan: National School of Development, Peking University, Beijing 100871, China. Zhang: China Center for Economic Research (CCER), Peking University, Beijing, 100871, China \& International Food Policy Research Institute (IFPRI), 2033 K Street, NW, Washington, DC 20006, USA. Corresponding author (Zhang): x.zhang@cgiar.org. 


\section{Introduction}

An emerging body of literature has found substantial support for the "fetal origins hypothesis" proposed by Barker (1992) that the in utero nutritional status shapes health outcomes in adult life. As reviewed in Almond and Currie (2011), prenatal exposure to malnutrition has a lasting damaging effect on the health of survivors. However, little is known about the impact on the children of the affected cohort in large part due to lack of data. The question as to whether the effects of health shocks are transmissible from one generation to the next has important implications on understanding intergenerational mobility and inequality.

In this paper, we exploit a natural experiment - the Great Chinese Famine of 1959-61 to explore the intergenerational legacy of prenatal exposures to the famine on cognitive abilities. Specifically, we employ the recently released 2010 and 2012 waves of the China Family Panel Studies (CFPS) to do so. In comparison to other data sources, CFPS is novel in that it has direct measures of cognitive abilities (math, verbal and short-term memory tests) for family members. The CFPS is also based on a nationally representative sample and includes extensive demographic information on respondents and their families that may be used as controls.

We focus on the cognitive outcomes of children born to parents who experienced famine during early childhood (i.e., those who were born during 1959-61) as measured by test scores. We find strong evidence that, relative to the control group (i.e., children born to parents who did not experience famine), daughters born to rural male (but not female) famine survivors performed worse in cognitive tests than sons. Why were only the daughters of rural famine fathers but not the children of famine mothers adversely affected? There are several potential explanations.

Culling and scarring are the two major effects of famine on survivors. Famines often result in excess mortality, the so-called "culling effect." The literature has established that the culling effect is particularly strong for males. It is widely documented that male fetuses are more likely to die than their female counterparts in the event of famine. As the fragile die, the fittest survive. Thus the presence of the culling effect implies a healthier survivor cohort. Famine also has a scarring effect. That is, survivors may suffer from lasting ill effects due to early exposure to the famine. It is an empirical question as to which effect dominates in the survivor population. 
We find that famine exposure in early childhood results in more damage to the cognitive abilities of female survivors than male survivors, suggesting that the culling effect likely dominates the scaring effect for males. This is consistent with other findings in the existing literature (Luo, $\mathrm{Mu}$, and Zhang, 2006; Song, 2010; Mu and Zhang, 2011).

The culling and scarring effects may have some genetic consequences. There is substantial evidence in the biology literature that the $\mathrm{X}$ chromosome is responsible for cognitive abilities (Turner, 1996); Badcock, 2009). There is also evidence that the X-linked genes inherited by daughters from their fathers potentially express themselves differently from those inherited from their mothers. Skuse (2005, page R30) finds that "maternally expressed X-linked genes might, therefore, influence hippocampal development, and paternally expressed genes influence the normal development of the caudate nucleus and thalamus in females." Recent work suggests that the thalamus, with its widespread cortical connections, plays a key role in human intelligence (Bohiken et al., 2013).

Since sons only inherit the $\mathrm{X}$ chromosome from their mothers while daughters inherit one from their mothers and one from their fathers, as Figure 1 makes clear, for the case where the father's X chromosome has been damaged by the famine, we would potentially observe girls with lower cognitive abilities in the second generations (sons would be largely unaffected). Under this hypothesis, if the mother's X chromosome was damaged by the famine, both sons and daughters should be equally affected. However, in our analysis, we do not find any effects for the children of scarred famine mothers.

We conclude that the scarring effect on female famine survivors is probably not large enough to make a dent on the subsequent generation. For the daughters of seemingly non-scared famine fathers to suffer the strongest effects would require evidence for an epigenetic mechanism that the damage to the $\mathrm{X}$ chromosome in famine fathers is expressed only in the next generation. We are unaware of any studies to support this view.

A second potential explanation is the socio-biological mechanism. For example, the seminal work by Belsky et al. (1991) proposed that early exposures to environmental stressors such as father's absence before age 7 were responsible for the early onset of puberty in daughters, as well as the latter's precocious sexuality and unstable relationships as adults. ${ }^{1}$

\footnotetext{
${ }^{1}$ There is some evidence that the father-daughter linkage may have genetic roots. Comings et al. (2002), for example, find that a variant X-linked androgen receptor (AR) gene that is passed on from fathers to their daughters
} 
However, in our sample, famine fathers actually have higher levels of education than non-famine fathers. Women born in the famine were married to men who were less educated and drank more, compared to the famine fathers (the comparison group). Hence, if father's negative characteristics were responsible for their daughter's outcomes, then daughters born to famine mothers should have performed worse in test scores than those born to famine fathers. But, that is not the case in terms of the results.

The third potential explanation has to do with economic reasons. It is possible that there are aggregate economy-wide or regional-specific factors that yield different returns to human capital by gender. Consequently, parents may be incentivized to invest more in or to engage in early intervention for affected children of one gender as opposed to the other. But, if that were the case, then, we would see similar gender differential effects for children regardless of being born to rural famine fathers or mothers in the same region. Yet, our results do not in fact reveal such similar effects.

The final explanation is related to son-preference. At the time of famine, families with strong son preference would tend to allocate their limited resources in favor of their sons than other families, and are thereby more likely to have survivor sons. It is conceivable that these male survivors, having grown up in a family with strong son preference, may take more early remedial interventions in favor of their sons, potentially at the expense of their daughters, to undo the damage from their exposure to famine. To test this hypothesis, we examine the intergenerational impact of first generational famine exposure on families with only one child as opposed to many, and also on families with only sons or daughters in comparison with families with children of both sexes. We find negative effects on girls born to famine fathers only if they have brothers, suggesting the persistence of intra-household son-preference. We conclude therefore that the pattern of intergenerational effects of famine is most likely explained by a combination of the weak scarring effects on the exposed generation and the stronger son

\footnotetext{
but not to their sons explains why fathers who are predisposed to behaviors such as family abandonment tend to have daughters who experience early puberty and also exhibit more aggressive and impulsive behavior, such as precocious sexuality, increased number of sexual partners, and sexual compulsivity. However, these recent findings do need to be treated with some caution. A replication exercise by Jorm et al. (2004) for the associations found in Comings et al. (2002) with the AR allele failed to produce substantively similar findings. Mustanski et al. (2004) also suggest that the relationship between the absence of fathers and adolescent development may be complex and may depend on gene-environment correlations. They give the example of mothers who enter puberty early being more likely to bear children earlier, which, in turn, predisposes the parental match to early separation. At the same time, these mothers' offspring inherit genes predisposing them toward early puberty.
} 
preference of male survivors.

The rest of the paper is organized as follows. We provide a literature review in section 2 . Section 3 details our methodology and describes the data. Section 4 discusses our findings. Finally, section 5 concludes.

\section{Literature Review}

We now review the existing literature on famine and early childhood malnutrition paying particular attention to the work related to the Great Chinese Famine of 1959-61. Since largescale randomized controlled trials on human beings are infeasible for a direct test of this hypothesis, researchers have relied on exogenous shocks, such as famines, to identify the negative effects of exposure to early childhood malnutrition on subsequent health and economic outcomes for the affected individuals. ${ }^{2}$

A seminal work in this area is Stein et al. (1972) on the lasting health impact of exposure to the 1944-45 Dutch Famine in early childhood. Stein et al. (1972) found that neither the incidence of famine experienced in utero nor during early childhood had significant effects on the cognitive abilities of male survivors at age 19 - measured in terms of IQ and mild or severe forms of mental retardation. However, subsequent work has found evidence that by middle age this cohort experienced significantly higher than average levels of health disorders including higher rates of obesity (Ravelli et al., 1999) and glucose intolerance (Ravelli et al., 1998), lower quality of self-reported health and higher rates of coronary heart disease morbidity (Roseboom et al., 2001, Bleker et al., 2005), and higher incidences of adult psychological disorders (Neugebauer et al., 1999; Brown et al., 2000; Hulshoff et al., 2000).

More recently, researchers have found that childhood exposure to famines has persistent long-run negative consequences in other countries. For instance, children in rural Zimbabwe who were exposed before the age of 3 to the effects of drought and civil war were significantly shorter at adolescence and had lower schooling attainment (Alderman et al., 2006). Neelsen and Stratmann (2011) highlighted the adverse yet heterogeneous effects of the 1941-42 Greek famine

\footnotetext{
${ }^{2}$ Other work in the development literature has also looked at other forms of early health shocks that are potentially not as severe as a deep famine spanning multiple years; e.g., fasting by mothers during Ramadan (Almond and Mazumder, 2011).
} 
on survivors below the age of 2 at the time of famine, i.e., the exposed cohort to famine during infancy (first year of life) performed much worse in terms of educational attainment than those exposed during the second year of life. Employing data from the Ghana Education Impact Evaluation Survey, Ampaabeng and Tan (2013) show that the 1983-84 famine in Ghana significantly lowers IQ and academic scores of Math and English comprehension tests for survivors who were between the ages of 0-2 during the time of the famine.

A particularly fruitful context for famine studies has been China. The Great Chinese Famine of 1959-61 has been argued to be one of the most severe in human history in terms of loss of life resulting in between 15-30 million excess deaths (Ashton et al., 1984; Riskin, 1990; Ravallion, 1997) and around 30 million lost or postponed births (Ashton et al., 1984; Yao, 1999). In perspective, the upper bound of excess deaths translated to $5 \%$ of the entire population. There was also substantially large geographic variation in famine severity with rural areas and provinces that showed highest support for the Party's policies (as measured by Party membership density; Kung and Lin (2003)), such as Henan, Sichuan, Anhui, Shandong, and Gansu, performing worse.

There is strong evidence that exposure to the famine had significant negative long-run consequences for survivors. Survivors of the 1959-61 birth cohorts have been shown to register less favorably on a range of adult health and economic outcomes including anthropometric health measures such as height (Chen and Zhou, 2007; Meng and Qian, 2009) and obesity (Luo et al., 2006), incidence of disability (Mu and Zhang, 2011), risk of mental illness (Huang et al., 2012), educational attainment (Meng and Qian, 2009), labor market experiences (Almond et al., 2010; Meng and Qian, 2009), wealth (Almond et al., 2010), and marriage market outcomes (Almond et al., 2010; Brandt et al., 2008). The famine also appears to have had differential impact on male and female survivors. As Almond et al. (2010, page 332) report, using data from China Population Census 2000, that "men were 9\% more likely to be illiterate, $6 \%$ less likely to work, and 6.5\% less likely to be married if exposed to the Famine in utero. Women were 7.5\% more likely to be illiterate and 3\% less likely to work, and tended to marry men with less education, if exposed in utero. We also find fetal exposure to the Famine substantially reduced the cohort's sex ratio (fewer males), suggesting greater male vulnerability to maternal malnutrition." 
While the long-run negative effects on survivors of early childhood exposure to famine have been well-documented, the question as to whether these effects for human population persist across generations is an open one. ${ }^{3}$ There have been a small number of recent works on the intergenerational persistence of early health shocks based on the China Health and Nutrition Survey, focusing primarily on general health measures. To our knowledge, no studies have examined the intergenerational impact on cognitive abilities in China. For instance, Li and An (2013) find that children born to both parents who were exposed to the Great Chinese famine were significantly shorter (adjusted for age) than children born to other parents. In addition, Fung and $\mathrm{Ha}$ (2010) show that the children of famine-exposed parents had lower weight adjusted for age, but their schooling attainment was no different from other children. Kim and Fleisher (2010) also find no significant negative effects on second-generation schooling and work status, but a negative impact on wages and work hours. Finally, using China Population Census 2000, Almond et al. (2010) found that consistent with the Trivers-Willard (1973) hypothesis, mothers who had been exposed prenatally to famine were more likely to give birth to daughters. Overall, most of the empirical studies on intergenerational transmission do not look at the gender-specific intergenerational transmissions and none of them has examined the impact on cognitive ability.

Since cognitive ability is an integral part of human capital, our paper is also related to the broad economics literature on international mobility (Black and Devereux, 2011; Clark, 2014). For example, Clark (2014) used the persistent overrepresentation of individuals with rare (high status) surnames in occupations with high social status to show that patterns of social mobility are actually relatively invariant over time. He asserts "a social law...a universal constant of intergenerational correlation of 0.75 , from which deviations are rare and predictable." The focus on surnames potentially attributes the low social mobility in many societies to inherited advantages from fathers to sons as the major cause. However, as shown in the biological literature, sons' cognitive skills should be more associated with the $\mathrm{X}$ chromosomes of their mothers. The high persistence of the father-son link may therefore not be due to pure genetic

\footnotetext{
${ }^{3}$ There are reasons to believe that there might be direct linkages across generations in terms of health. Jirtle and Skinner (2007) provide a comprehensive review of epidemiological evidence from mice studies providing strong support not only for the fetal origin hypothesis but also evidence that some of these environmental effects are passed on to subsequent generations. They further suggest that the transmission mechanism is epigenetic in origin. The Överkalix cohort studies by Pembrey et al. (2006) have also provided evidence for sex-specific, male-line transgenerational effects of limiting food supplies whereby grandsons (but not granddaughters) of paternal grandparents who faced limited food supplies in early childhood experienced higher mortality risk ratios.
} 
reasons. Black, Devereux, and Salvanes (2005) also show that only mothers' education has a causal impact on sons' education level. But the impact of fathers on children is more muted. Following Black, Devereux, and Salvanes (2005), we also explore the dyadic relationships between children's cognitive abilities and those of the affected famine parents.

\section{Data and Methodology}

We now describe the data we used for our analysis and our baseline exercise. Our main dataset in the empirical analyses is the CFPS, which is a panel survey data set conducted in 2010 and 2012. The CFPS data collection effort was funded by the 985 Program of Peking University and carried out by the Institute of Social Science Survey of Peking University. The aim was to characterize the transitions of social, economic, demographic, education and health situations in China and provide the data foundations for academic and public policy research. The CFPS 2010 covers 14,798 families and 33,600 adults taken across 25 provinces of China.

This dataset has two advantages. First, it carries out a cognitive test of the respondents, which is a direct measurement of cognitive ability. Previously, people have employed indirect outcome indicators, such as literacy or schooling attainment, to measure cognitive ability. Specifically, CFPS 2010 prepared a series of mathematics and word recognition questions for the respondents to answer, while CFPS 2012 replaced the above tests with short-memory and logic tests. The questions are arranged in ascending order of difficulty within groups of questions indicated by the highest education level of the respondent. The ultimate test score is the order (rank) of the hardest question that the respondent is able to answer correctly; if the respondent fails to answer any question in his education group correctly, his score is the lowest for his education level minus 1. For example, a person with middle school education will begin to answer from the 9th question. If the hardest question that the respondent is able to answer correctly is the 11 th question, his test score is 11 . If he fails to answer questions 9,10 , and 11 consecutively, his score is 8 (9-1).

Second, CFPS provides detailed individual, family, and community information about the respondents, which allows us to introduce a rich set of controls when analyzing the effects of parental exposure to famine on children's cognitive ability. For example, CFPS asks about the time to the nearest hospital and the distance to the nearest high school, two important 
determinants of whether the respondent (or his family) is able to get access to medical service and education systems conveniently, which in turn potentially affects cognitive development. Furthermore, the height, weight, and health status of the respondent are also available from CFPS 2010, which enable us to exclude the impact of potential (early) health interventions on cognitive ability.

In this paper, we are particularly interested in the potential heterogeneous impact of the famine along two dimensions. First, we want to know whether the effect on children of male survivors (famine fathers) is different from that for female survivors (famine mothers). In order to do that, we separate the father and mother samples. Second, we are interested in whether there is heterogeneous impact across the genders of children. We therefore allow for the famine effect to vary across female and male children of famine survivors in our analysis.

We restrict our sample to rural areas because the famine mainly struck there due to urban biased policy. As argued in Chen and Zhou (2007), the strict hukou system (household registration) in that period prevented rural people from migrating to the urban areas.

Formally, our baseline econometric specification is as follows:

$$
y_{i}=\beta_{1} \text { cohort }_{i} \times \text { excess_mortality }{ }_{p}+\beta_{2} \text { cohort }_{i}+\beta_{3} \text { excess_mortality }_{p}+X_{i}^{T} \gamma+\varepsilon_{i}
$$

where $y_{i}$ is the test score for individual $i$ (with higher scores indicating better cognitive ability), and cohort $_{i}$ is a dummy variable which equals 1 if the respondent's father (mother) was born during 1959-1961, i.e., the famine years, and equals 0 otherwise. Recall that our aim is to investigate the cognitive impact of the famine on the children of famine survivors who had experienced famine in the fetal stage. Considering that the famine ended in most provinces in 1961 but in some provinces in 1962, and people born in 1962 might or might not have been conceived during the famine years, we exclude the children whose parents were born in 1962 from our sample. We choose the children whose parents were born during 1963-1965 as the control group. The children themselves (both cohorts) were in early adulthood (aged 16-30) at the times of the surveys. Our proxy for famine intensity in province $p$ (excess_mortality ${ }_{p}$ ), taken from Lin and Yang (2000), is defined as the difference between the highest mortality rate in 1959-1961 and the average mortality rate in 1956-1958 in the province. 
The main coefficient of interest in our analysis is $\beta_{1}$ of equation (1). While the level term, $\beta_{2}$, captures the intrinsic difference in cognitive test scores between the children of famine survivors and non-famine survivors, the coefficient to the interaction term of cohort $_{i}$ and excess_mortality $_{p}, \beta_{1}$, captures the diverse impact of the Great Famine on the cognitive development of descendants of famine survivors relative to non-famine survivors. Note that the partial effect of the intensity of famine on the former group is given by $\left(\beta_{1}+\beta_{3}\right)$ while that for the latter is given by just $\beta_{3}$. Since the latter group has not experienced the famine, we expect $\beta_{3}$ to be insignificant from 0 . This then constitutes a natural falsification test. A negative $\beta_{1}$ would then imply a detrimental effect of the Great Famine on the children of famine survivors.

The set $X_{i}$ denotes the set of controls including the individual, family, and community characteristics of the respondent. In terms of individual characteristics, we control for gender, age, birth order, log of height, log of weight, and health status (in good health) of the respondent. We also include the square and cubic terms of age to capture the potential nonlinear effect of age on cognitive ability. Since parents' age difference may affect children's cognitive performance, we include the age difference between fathers and mothers as a robustness check. Finally, we also include region and ethnicity fixed effects to allow for systematic differences in cognitive test scores across different regions and ethnic groups in China.

Birth order might affect cognitive ability because the youngest child potentially receives more attention from parents and may get access to better education considering the rapid development of China's education system in the past 30 years. Height and (to a lesser extent) weight are highly correlated with nutrition in early childhood, which is a critical determinant of cognitive development. We also employ a survey question to get a respondent's current health status. The question, "in good health", is a subjective evaluation by the respondent, which equals 1 if the health status is moderate or good and 0 otherwise. Other family-level control variables that might affect the level of investment in the child include the number of siblings, parents' education level, and family income per person. At the community level, we include time to nearest hospital and distance to nearest school as these variables capture the local accessibility of medical services and education.

Table 1(a) provides summary statistics for the key variables, while Table $1(\mathrm{~b})$ provides a breakdown of the key demographic and family characteristics of households with various 
parental pairs. Figure 2 shows the trend in the difference in the math test scores for children of rural fathers born in areas that experienced severe famine in 1959-61 compared to those born in regions with less severe famine. What stands out in the figure is the sharp spike in the mean difference of math test scores for the daughters of fathers who were born during the famine, the peak of which was in 1960 and 1961, between severe and less severe provinces. Of course, the figure just presents suggestive evidence on the link between fathers' fetal exposures to famine and daughters' worse math performance. In the next section, we will provide more quantitative evidence to substantiate the causal relationship.

\section{Findings}

\subsection{Baseline Findings for the Second Generation}

We first carry out a simple difference-in-differences exercise comparing the intergenerational cognitive effect of fathers in severe and less severe regions who experienced famine in early childhood (i.e., those born in the years 1959-61) as opposed to those who have never experienced famine (i.e., those born in the years after the famine (1963-65)). We report the difference-indifferences results in Table 2. The results show a significant negative effect on Math test scores for the children of fathers who experienced famine during early childhood with the effect being particularly large and significant for their daughters. In a similar difference-in-differences exercise (results not reported) for the children of famine mothers, however, we do not find significant effects for children of either gender.

The findings for the simple difference-in-differences exercise are upheld by the results based on our baseline specification, which are reported in Table 3. Table 3 shows the regression results for the intergenerational impact of the famine on the Math test scores of children whose fathers were born in the rural area during 1959-65 (spanning the years of the famine and after except for 1962). Consistent with our hypothesis, we find a negative coefficient for the interaction between famine severity and the father being born during the famine years of 1959-61 (corresponding to $\beta_{1}$ of equation (1) above) for the entire set of children. This finding is true regardless whether we explicitly exclude provincial fixed effects (column (1) of Table 3) or include them (column (2) of Table 3). 
When we examine the breakdown of the findings by the gender of the children, we find substantial gender difference. The findings are shown in columns (3) and (4) of Table 3 for male offspring and columns (5) and (6) of Table 3 for female offspring. While father's exposure to famine during early childhood lowers Math test scores for both male and female offspring, only the impact for girls is statistically significant. The magnitude is also large. An increase of famine intensity by one standard deviation will increase the difference in Math test scores between daughters whose fathers were born during the Great Famine and those whose fathers were not by 9.6 percent. In fact, we find that in provinces where the famine was severe (as defined in Table 2), the difference in Math test scores between girls of famine and non-famine fathers is a massive $27 \%$, while in less severely exposed provinces, the difference is not significant.

\subsection{Robustness and Falsification Checks}

We next conduct a sequence of robustness checks and falsification tests. First, we want to rule out that the observed pattern is driven by an existing trend prior to the famine across regions. In Table 4, we regress Math test scores of children whose fathers were born in 1953-59 on a set of cohort fixed effects and their interactions with the famine variable. None of the coefficient for the cohort and their interaction terms with famine is statistically significant. It is apparent from the table that there are no pre-existing differences in Math test scores across the children of birth cohorts from 1953 to 1958 (relative to the base cohort of 1959).

Moreover, we also check whether the difference across provinces already exists before the famine. Similarly as Table 2, we calculate the mean of math scores in severe and less severe provinces for the children of rural fathers born in 1956-1958. For the full sample, the figures are 14.38 and 14.50, respectively. It is not significant even at the $10 \%$ significance level. The difference is not significant for the boys' sample (14.47 vs. 14.22) and girls' sample (14.23 vs. 14.87), either. Therefore, there is no systematic difference among different provinces before the famine.

It is possible that the calculation of excess mortality at the province level may be subject to measurement error. To address this possibility, we investigate what happens when we employ the reduction in the cohort size of 1959-1961 relative to 1956-1958 at the county level as an alternative measurement for the severity of famine. In this case, the data for the cohort size is 
from the 1\% sampling of the China Population Census in 2000. We report the corresponding results based on the county-level famine measure in Table 5. The results are qualitatively similar to what was found using the province-level famine measure.

Another source of measurement error may stem from migration. The observed population in 2010 might not be born in the same place. There are two facets to this problem: migration of parents and migration of their children. Massive migration did not take place until the late 1990s and most of the migrants were younger than 30 years old (Meng, 2012). Since the 1959-1961 and 1963-1965 cohorts were already more than 30 years old in the late 1990s, the issue of migration is not a big problem for famine parents. However, migration of children potentially poses a challenge for our baseline analysis. If cognitively higher functioning children tend to migrate to the urban area, the observed rural sample is then composed of cognitively weaker children, thereby more likely to exaggerate the negative impact of the famine. Fortunately, CFPS 2010 asks the respondents about where they are currently living and their birthplace so that we are able to deal with the migration problem directly. In Table 6, we report results for the cases by excluding respondents whose current domiciles are different from their birthplaces from the sample. The results continue to hold.

It may also be the case that the CFPS is not a representative sample of the Chinese population (even though it was explicitly constructed to be the case). To check against this possibility, we conduct a similar baseline analysis using data from the Chinese Population Census of 2000. Unfortunately, the census data does not have many good measures of cognitive abilities. We chose the dependent variable to be the illiteracy dummy and checked if our baseline findings continue to hold when we use this dataset (that no one disputes in terms of representativeness). As Table A1 of the Appendix shows, our baseline findings are qualitatively robust. The negative cognitive effects are found to be statistically significant at the $5 \%$ level only for children of fathers who experienced the famine during early childhood. The impact is much larger for daughters than for sons.

It is also possible that the findings are specific to the Math test and that alternative measures for children's cognitive ability may yield substantively different results. As Table A2 of the Appendix shows, however, the findings for the Math test are similar to those obtained when we use the Word recognition test scores from the CFPS 2010 as an alternative measure of cognitive ability. There is also preliminary data (not as yet publicly available) from the 2012 
wave of the CFPS on scores for a Short-Term Memory test. We carry out a similar baseline regression exercise for this cognitive dependent variable; see Table A3 of the Appendix. The results for the Short-Term Memory test are consistent with what we obtained with the Math test scores for the CFPS 2010 data. Yet again, sons of famine fathers do better on the test than daughters of famine fathers. In both cases, similar to the Math test results, the magnitude of the (statistically significant) intergenerational effects is large. An increase of famine intensity by one standard deviation will increase the difference in Word test scores between daughters whose fathers were born during the famine and those whose fathers were not by 30.7 percent. For the Short-Term Memory test, sons of famine fathers achieve a 5 percent higher score than those of non-exposed fathers.

We note that similar findings are not present when we consider the set of rural famine mothers. We show corresponding regression results for the Math and Word test scores (Table A4 of the Appendix) as well as Short-Term Memory test scores (lower panel of Table A3) for children born to rural mothers. In all cases, we do not find any intergenerational effect from mothers to their children of either gender. The intergenerational transmission of the negative effects of early health shocks to parents (fathers, in particular) is therefore gender-specific (affects only daughters significantly).

As we noted in section 3 , the coefficients to the Famine variable (corresponding to $\beta_{3}$ of equation (1) above) in columns (1), (3), and (5) of Table 3 describe the effects of the severity of famine on children of fathers who were born after the famine years. A natural falsification check would be that these coefficients should be insignificant from 0 . We see from Table 3 that this is in fact the case. As a further falsification test, we also conduct the same analysis as in our baseline exercise on the urban sample. Since the famine mainly took place in the rural regions, the negative intergenerational effects we observe in the rural areas should not be observed for children of parental cohorts born in the famine years but living in urban areas. Reassuringly, we find the expected patterns in the falsification test (see the upper panel in Table 7).

The observed results may also be due to the systematic difference in mothers' age in the famine father and mother samples. Since men tend to marry younger women, mothers are on average younger in the famine father sample than those in the famine mother sample. If a child's cognitive performance is associated with mother's age at his/her birth, then the difference in mothers' age between the two samples may result in a systematic bias. To address this concern, 
one method is to run a falsification test by comparing two post-famine cohorts, 1963-1965 and 1966-1968. If mothers' age is a driving factor, it will manifest in the falsification exercise as well. As shown in the lower panel of Table 7, none of the coefficients for the 1963-1965 cohort and its interaction term with famine is statistically significant, largely dismissing this concern. Another method to deal with this concern is to control the age difference between fathers and mothers. As shown in Table A5 of the Appendix, the basic patterns remain robust when we include this control variable. Therefore, the systematic difference in mother's age in famine fathers' and famine mothers' samples is not a big challenge to our baseline results.

\subsection{Endogeneity}

While our approach of using the excess death rate as a proxy for the intensity of famine is consistent with most of the existing work in the literature, the use of this proxy has several known drawbacks. The purpose of this proxy is to measure the severity of experienced malnutrition during the famine. Although malnutrition would certainly be a cause of excess mortality, other factors associated with the incidence of famine in a given region could contribute to (or detract from) excess mortality too. Such factors include migration in or out of a region (although this factor is less important in the Chinese context due to the existence of strict regional migration restrictions in the form of the hukou system), and the degradation of medical and social services, etc. The excess death rate therefore is likely to be endogenous.

To address the issue of endogeneity, we propose instrumental variables that take advantage of the unique institutional features of the Chinese administration during the famine years. Specifically, our IVs target the performance assessment system imposed by the central government on provincial governors and secretaries. Some studies (Li and Yang, 2005; Kung and Chen, 2010) have shown that the origins of provincial governors matter greatly to the famine severity. Governors accumulated promotion capital from the central government when they met what were radical and, in many cases, unattainable grain production targets under the Great Leap Forward movement in 1958. Governors were therefore incentivized to inflate grain output figures (resulting in excessive grain procurements by the central government), and/or redistribute grains to other provinces to win favor with the central government. With distorted information, the central government, as a consequence, failed to take relevant steps to lower the output target 
and transfer grains to the provinces suffering from severe famine (Cai, 2000). As Meng et al. (2011) point out, the inflated grain output and the subsequent over-procurement of grains produced a striking geographic pattern of famine that had reversed previous mortality trends under normal conditions. Regions that had historically produced more grain and had experienced historically lower mortality rates suffered more during the famine.

Our IV strategy builds on the story of Meng et al. (2011) and is related to the approach by Meng and Qian (2009) as well as the broader literature on official incentives and economic performance in China (Li and Zhou, 2005). When a governor had strong local ties, he potentially had better information about the actual degree of famine in his province (e.g., by hearing from his relatives or close friends who were experiencing the famine firsthand). However, the governor could also count on his strong local ties to allow him to get away with activities such as counterfeiting output information thereby aggravating the severity of the famine (via overprocurement) in that province. We therefore instrument famine intensity with a dummy variable denoting whether the birthplace of the provincial governor/secretary who was in charge of the province during the famine period was, in fact, in that province. We also employ alternative weather-related IVs that are standard in the literature including flood incidence from trend and rainfall deviation from trend although there appears to be little evidence that weather conditions were primary determinants of the famine (Lin and Yang, 2000).

We present the first stage and second stage results of our 2SLS regressions in Table 8(a) and Table 8(b), respectively. Table 8(a) establishes that governor's birthplace is a valid IV for famine severity. In the first stage regression, governor's birth place is significantly associated with the severity of famine. Its interaction with the cohort dummy also predicts the interaction of famine severity and the cohort dummy. One may suspect that some provinces may always have governors born locally due to some unobserved factors, which may be also correlated with the outcome variables. We check the birth places of provincial governors for later years and do not find any systematic patterns. We also ran a placebo test for the IVs. If we use the birth place of governors in non-famine years as an instrument, the instrument does not have any predicative power on the famine severity observed in 1959-1961 ${ }^{4}$. For the second stage regressions, Table 8(b) shows that the endogeneity tests reject the null hypothesis of exogeneity in some

\footnotetext{
${ }^{4}$ The results are not reported due to space limitations. They are available upon request.
} 
specifications, validating the use of 2SLS. Furthermore, Hansen statistics do not reject the null hypothesis of correct specification in all cases. Our 2SLS estimates not only qualitatively affirm those of our baseline (OLS) results, but also yield much larger negative impact on daughters (three times as large).

A second drawback of employing a mortality variable as a measure of famine intensity is potential mortality selection. In this case, our concern is with potential mortality selection for the children of famine survivors. If an effect of famine on survivors is that only relatively strong children of theirs survive compared to the children of the non-exposed parents, then this selection could result in potential bias in the estimation of the intergenerational cognitive impact of early exposure of the parents' generation to famine.

We (partially) address the issue of mortality selection by appealing to the strategy proposed by Meng and Qian (2009). We compare the famine effect across particularly fit individuals (for whom the survivor bias would conceivably be less relevant) according to the outcome variables by running quantile regressions for the upper quantiles (e.g., $80^{\text {th }}$ percentile and $90^{\text {th }}$ percentile); see Table 9. As Meng and Qian point out, we have to be cautious about interpreting the upper quantile effects as the mean effect since there is no way of distinguishing possible heterogeneous effects for individuals at different quantiles of the distribution of outcomes from potentially similar patterns arising from survivor selection. Nevertheless, it is at least comforting that we find that our main results generally hold in the upper quantiles, and, in particular, that our finding of the differential (stronger) effect for daughters is quantitatively larger at the $90^{\text {th }}$ percentile. Overall, these results provide some support (conditional on this caveat) for the proposition that our baseline findings are not driven by survivor bias.

\subsection{Mechanisms}

We now explore the possible mechanism that drives our findings for the intergenerational effect. We first investigate the impact of the famine on the cognitive abilities of the first generation (famine survivors), which will help us understand the mechanisms more clearly and put our findings in line with other studies. Table 10 (Panel A) shows the impact of famine on the Math test scores of all famine survivors, as well as separately for male and female survivors. Table 11 (Panel A) shows the corresponding results using a measure of cognitive disability from the China 
National Survey of Disabled People in $2006 .{ }^{5}$ The results in both cases are consistent. The impact of the famine on the cognitive abilities of male survivors is insignificant whereas the impact on female survivors is negative and significant at the $1 \%$ level. However, even in the case of female survivors, the magnitude of the impact is modest compared with those for the second generation. For instance, for the Math test, we find that an increase of famine intensity by one standard deviation will increase the difference in Math test scores between female famine survivors and non-famine females by around 5.9 percent.

We also rule out any strong selection effects in the marriage/mating market for first generation survivors. Even though there may be strong scarring effects on the first generation, it does not necessarily mean the impact carries over to the next generation. Heavily scarred first generation survivors may fail on the marriage/mating market and produce no children. This failure would mitigate the transmission of first generation shocks to future generations of the population. Alternatively, if there is strong assortative matching in the marriage/mating market, then the worst scarred survivors may end up with the least fit mates. In this case, the intergenerational transmission of shocks to the first generation may be reinforced.

To analyze the effect of marriage/mating selection on survivors, we need to compare the outcomes of survivors who (i) got married with people who also got married but were not exposed to the famine (see, Panel B of Tables 10 and 11), and (ii) got married and had children with the corresponding non-exposed control group (see, Panel $\mathrm{C}$ of Tables 10 and 11). In both cases, we found little evidence of marriage/mating selection in terms of any systematic patterns of marriage failure in the survivor population. However, when we compare the household characteristics of married famine male survivors and married famine female survivors with those of the control group, we do find that married famine female survivors experience less desirable matches on the marriage market; see Table 1(b).

\footnotetext{
${ }^{5}$ The survey was conducted jointly by the National Bureau of Statistics, Ministry of Civil Affairs, and China Federation of Disabled People in 2006. The survey covers 31 provinces, autonomous regions and municipalities. Eliminating abnormal values resulting from input errors, the dataset ends with 2,369,496 individuals. The sample is quite random and representative. The survey includes individuals' basic information and their economic, social, and disability status. Basic information refers to an individual's age, gender, family address. Economic and social status is reflected by school attainment, personal income and marital status. Disability information is more detailed, consisting of disability status, pathogenic causes and degree of severity, and his/her most urgent requirement. All of the disabilities are classified into five categories: visual, hearing and speech, cognitive, mental and physical disability.
} 
Since in the CFPS, it is possible that a parent took the test but his/her child did not due to the fact that they were out of the home, there might also be systematic differences between parents whose children took the test and those whose children did not. To exclude this possibility, in panel D of Table 10, we further restrict the sample to those parents whose children took the test. The basic patterns continue to hold and thus sample selection is not a serious issue considering the similar patterns across different samples.

Since only female survivors showed (modest) scarring effects from exposure to the famine, and their children appear not to show any intergenerational impact, we conclude that the culling effect of the famine was sufficiently strong so that the scarred surviving females were not badly scarred enough to experience discrimination on the marriage market (as shown), and evidently were not sufficiently deeply scarred in order to transmit a significant impact to their children. The question remains therefore as to why male survivors who appear to be not scarred by famine exposure nevertheless go on to have daughters who are disadvantaged.

A leading hypothesis is son-preference by this group of parents. To examine the possibility of son-preference, we investigate the intergenerational impact of first generational famine exposure on families with only one child as opposed to many (see Table 12 for famine fathers and Table A6 of the Appendix for famine mothers) and also on families with only sons or daughters in comparison with families with children of both sexes (see Table 13 for famine fathers and Table A7 of the Appendix for famine mothers). For famine fathers, we find that for the case where there is only one child in the family, regardless of whether that child is a boy or a girl, the child does not do worse than the corresponding control group. It is only in the case when the famine father's family has more than one child and in the case when there are both sons and daughters in the family where we see the negative intergenerational impact of first generation famine exposure on girls. We do not see impact on the second generation across any family types for famine mothers. It appears therefore that our baseline findings for the intergenerational impact of famine exposure in section 4.1 are entirely driven by the low performance of girls in families with both sons and daughters. The evidence therefore points to the conclusion that the intergeneration effects are a result of rural fathers who experienced famine in childhood exhibiting strong son preference (while rural mothers who experienced famine in childhood do not or have preferences that are too weak to make a difference). 
Is son-preference by rural fathers entirely attributable to cultural attitudes? The different proclivity of son preference in different minority groups in China provides us with an opportunity to test this hypothesis. However, the drawback of the CFPS 2010 dataset is that it does not cover ethnic minority autonomous regions except for Guangxi. The limited number of minority group people in the CFPS 2010 dataset prevents us from investigating this question thoroughly using the CFPS data. The 1\% Sample of the Population Census in 2000, however, covers every province in China and thus presents us with a possible solution. As noted above, the weakness of the census data is that it does not conduct any cognitive tests and the set of controls is much more limited than those in the CFPS as the former's focus is only on demographics. As before, we exploit the illiteracy dummy as our dependent variable in the following exercise.

In order to exclude those people who are illiterate because they are too young, we restrict our sample to those aged $13-20^{6}$. We then include in our baseline regression a dummy variable (Ethnicity) indicating ethnic groups that exhibit no son preferences (i.e., Hui, Uyghur, Mongolian, Tibetan, Li, and Dai). The classification is from Chen and Chen (2004) who review the sociology and anthropology literature on the fertility culture of the major ethnic groups in China; see also, Mu and Zhang (2011). We also interact the Ethnicity dummy with the interaction term between famine severity and the father being born during the famine. The coefficient to this two-way interaction then characterizes whether the diverse impact of famine on the children of famine cohorts differs between the ethnic groups having no son preference and the groups that do. We report our findings in Table 14. As we can see, the negative effects on daughters (recall that a positive coefficient implies higher rates of illiteracy) are even stronger for the ethnic groups without son-preference.

We therefore conclude that the son-preference exhibited by rural famine fathers is unlikely to be entirely driven by culture across ethnic groups. Given that famine fathers head households of generally higher socio-economic status (see Table 1(b)), the son preference by famine fathers may be a result of the generally higher socio-economic status of their households (Wei et al. 2013). These fathers may rationally prefer to maximize the outcomes of their sons because they expect a high marginal return on investment in terms of improving their sons' probability of success in the marriage market. The famine mothers belong to socio-economically

\footnotetext{
${ }^{6}$ In China, children usually begin their junior middle school at the age of 13.
} 
less successful households where the returns to such investments may be low ${ }^{7}$.

There is also likely another channel of son-preference persistence across generations within a family. Parents with strong son preference might have allocated limited resources in favor of sons at the time of famine to make sure their sons survive the famine. As the male survivors got married and had children, their mothers (now paternal grandmothers) would take care of the grandchildren. Their embedded son-preference attitude could play a role in generating gender difference in cognitive ability among their grandchildren. However, we cannot empirically distinguish between these two channels owing to data limitations, although the question deserves future research.

\section{Conclusion}

In this paper, we examine the intergenerational impact of a severe shock - the Great Chinese Famine of 1959-61 - on the cognitive abilities of the children of famine survivors. We do not observe any significant damage to the cognitive abilities of the first generation male survivors and we see only small negative effects on female survivors. This is in contrast to studies that focus on anthropometric measures where the scarring effects on survivors are sometimes found to be more prominent.

We find evidence for an intergenerational legacy from the famine only for daughters born to famine fathers. Children born to famine mothers do not reveal any disadvantage in cognitive ability despite some scaring effect on mothers. The gender difference in the effects on children born to famine fathers can be largely attributed to son-preference exhibited in families with fathers who were exposed to the famine in early childhood. Even if there is some negative effect on the daughters of famine fathers, it is unlikely to be passed on to the third generation as shown in the resilient performance among the children of the famine mothers. Overall, our findings

\footnotetext{
${ }^{7}$ It's possible that mothers also affect the degree of son-preference in the famine fathers' families. However, since men are more susceptible to famine, the cohort size of famine fathers is much smaller. They may have more bargaining power in the family due to their limited number. In terms of personal characteristics, they are not worse than the population average (or even better) due to selection effect, which are reflected in the summary statistics of Table 1. Similarly, fathers in the famine mothers' families may also influence the degree of son-preference in the family. However, in terms of summary statistics from Table 1, famine mothers usually end up with worse males. They are more on a par with their husbands and as a result, the son-preference may be weak in the family. A detailed investigation of the bargaining power and diverse degrees of son-preference in different families is not the focus of the paper, which deserves further research.
} 
suggest that human populations are extremely resilient to severe shocks, such as the Great Chinese Famine, in that most offspring of the cohort born during shocks are insulated from damage to their cognitive abilities.

This raises some hopes for the offspring of the poor in developing countries. Despite the poor's daily struggle for survival, they have passed cognitive genes to their offspring largely intact. With adequate food and nutrition, their offspring have the potential to thrive and become productive citizens. 


\section{References}

Alderman, H., J. Hoddinott, and B. Kinsey (2006) "Long Term Consequences of Early Childhood Malnutrition," Oxford Economic Papers, 58(3), 450-474.

Almond, D., L. Edlund, L. Hongbin, H. Li, and J. Zhang (2010) "Long-Term Effects of Early-Life Development: Evidence from the 1959-1961 China Famine," In The Economic Consequences of Demographic Change in East Asia, NBER-EASE, 19, Edited by Takatoshi Ito and Andrew Rose, 321-345, University of Chicago Press.

Almond, D. and J. Currie (2011) "Killing Me Softly: The Fetal Origins Hypothesis," Journal of Economic Perspectives, 25(3), 153-72.

Almond D. and B. Mazumder (2011) "Health Capital and the Prenatal Environment: The Effect of Ramadan Observance during Pregnancy," American Economic Journal: Applied Economics, 3(4), 56-85.

Ampaabeng, S. and C. M. Tan (2013) "The Long-Term Effects of Childhood Malnutrition on Cognitive Development: The Case of Famine in Ghana," Journal of Health Economics, 32(6), 1013-1027.

An, L. and Q. Li (2013) "Intergenerational Health Consequences of the Great Famine on Children in Rural China," working paper, University of North Florida.

Ashton, B., H. Kenneth, A. Piazza, and R. Zeitz (1984) "Famine in China, 1958-61," Population and Development Review, 10(4), 613-645.

Babcock, C. (2009) The Imprinted Brain: How Genes Set the Balance of the Mind Between Autism and Psychosis, $1^{\text {st }}$ Edition, Jessica Kingsley.

Barker, D. J. P. (1992) “The Fetal Origins of Diseases of Old Age," European Journal of Clinical Nutrition, 46, S3-S9.

Belsky, J., L. Steinberg, and P. Draper (1991) "Childhood Experience, Interpersonal Development, and Reproductive Strategy: An Evolutionary Theory of Socialization,” Child Development, 62, 647-670.

(2011). "Recent Developments in Intergenerational Mobility," in Handbook of Labor Economics, Edited by David Card and Orley Ashenfelter, page 1487-1541, Elsevier.

Black, Sandra E., Paul J. Devereux, and Kjell G. Salvanes (2005) "Why the Apple Doesn't Fall Far: Understanding Intergenerational Transmission of Human Capital." American Economic Review, 95(1): 437-449.

Bleker O. P., T. J. Roseboom, A. C. J. Ravelli, G. A. van Montfans, C. Osmond, and D. J. P. Barker (2005) "The Impact of Maternal Nutrition on the Offspring," Nestl'e Nutrition Workshop Series Pediatric Program, 55, 183-195.

Bohlken M. M. , Brouwer R. M., Mandl R. C., van Haren N. E., Brans R. G., van Baal G. C., de Geus E. J., Boomsma D. I., Kahn R. S. , Hulshoff Pol H. E. (2013) "Genes Contributing to Subcortical Volumes and Intellectual Ability Implicate the Thalamus," Hum Brain Mapp, forthcoming. 
Brandt, L., A. Siow and C. Vogel (2008) "Large Shocks and Small Changes in the Marriage Market for Famine Born Cohorts in China," Society for Economic Dynamics, Meeting Papers 264.

Brown, A.S., J. van Os, C. Driessens, H. W. Hoek, and E. S. Susser (2000) "Further Evidence of the Relation Between Prenatal Famine and Major Affective Disorder," American Journal of Psychiatry, 157, 190-195.

Cai, Y. (2000) "Between State and Peasant: Local Cadres and Statistical Reporting in Rural China," The China Quarterly, 163, pp. 783-805.

Chen, C. and S. Chen (2004) The Fertility Culture of Minorities (Shaoshu Minzu Shengyu Wenhua), China Population Press, Beijing.

Chen Y. and L. Zhou (2007) "The Long-Term Health and Economic Consequences of the 1959-1961 Famine in China," Journal of Health Economics, 26, 659-681.

Clark, Gregory (2014) The Son Also Rises: Surnames and the History of Social Mobility. Princeton University Press, Princeton.

Comings, D. E., D. Muhleman, J. P. Johnson, and J. P. MacMurray (2002) "Parent-Daughter Transmission of the Androgen Receptor Gene as an Explanation of the Effect of Father Absence on Age of Menarche," Child Development, 73, 1046-1051.

Fung, W. and W. Ha (2010) "Intergenerational Effects of the 1959-61 China Famine," in Risk, Shocks, and Human Development on the Brink, Palgrave Macmillan, 222-54.

Huang, C., M. Phillips, Y. Zhang, Q. Shi, Z. Song, Z. Ding, S. Pang and R. Martorell (2012) "Malnutrition in early life and adult mental health: Evidence from a Natural Experiment," Social Science \& Medicine, 97, pp. 259-266.

Hulshoff Pol, H.E., Hoek, H.W., Susser, E., Brown, A.S., Dingemans, A., Schnack, H.G., van Haren, N.E., Pereira Ramos, L.M., Gispen-de Wied, C.C., and Kahn, R.S. (2000) "Prenatal Exposure to Famine and Brain Morphology in Schizophrenia," American Journal of Psychiatry, 157, 1170-1172.

Jirtle, R. L. and M. K. Skinner (2007) "Environmental Epigenomics and Disease Susceptibility," Nature Reviews: Genetics, 8, 253-262.

Jorm, A. F., H. Christensen, B. Rodgers, P. A. Jacomb, and S. Easteal (2004) "Association of Adverse Childhood Experiences, Age of Menarche, and Adult Reproductive Behavior: Does the Androgen Receptor Gene Play a Role?” American Journal of Medical Genetics Part B, 125, 105-111.

Kim, S. and B. M. Fleisher (2010) "The China Great Leap Forward famine: The Lasting Impact of Mothers' Fetal Malnutrition on Their Offspring," Working paper, Ohio State University.

Kung, J. K. and J. Y. Lin (2003) “The Causes of China's Great Leap Famine, 1959-1961,” Economic Development and Cultural Change, 52(1), 51-73.

Kung, K. S. and S. Chen (2010) "The Tragedy of the Nomenklatura: Career Incentives and Political Radicalism during China’s Great Leap Famine,” American Political Science Review, 105, 27-45. 
Li, W. and D. T. Yang (2005) "The Great Leap Forward: Anatomy of a Central Planning Disaster," Journal of Political Economy, 113, 840-877.

Li, H. and L. Zhou (2005) "Political Turnover and Economic Performance: The Incentive Role of Personnel Control in China," Journal of Public Economics, 89, 1743- 1762.

Lin, J. Y. and D. T. Yang (2000) "Food Availability, Entitlements and the Chinese Famine of 19591961," Economic Journal, 110, 136-158.

Luo, Z., R. Mu, and X. Zhang (2006) "Famine and Overweight in China," Review of Agricultural Economics, 28 (3), 296-304.

Meng, X. and N. Qian (2009) "The Long Term Consequences of Famine on Survivors: Evidence from a Unique Natural Experiment Using China’s Great Famine,” NBER Working Paper 14917.

Meng, X. (2012) "Impact of Economic Reform on Labor Market Outcomes in China," Journal of Economic Perspective, 26(4), 75-101.

Meng, X., N. Qian, and P. Yared (2011) “The Institutional Causes of Famine in China, 1959-61,” NBER Working Paper w16361.

$\mathrm{Mu}, \mathrm{R}$. and X. Zhang (2011) "Why Does the Great Chinese Famine Affect the Male and Female Survivors Differently? Mortality Selection versus Son Preference," Economics and Human Biology, 9, 92-105.

Mustanski, B.S., R. J. Viken, J. Kaprio, L. Pulkkinen and J. R. Rose (2004) "Genetic and Environmental Influences on Pubertal Development: Longitudinal Data From Finnish Twins at Ages 11 and 14," Developmental Psychology, 40(6), 1188-1198.

Neelsen, S. and T. Stratmann (2011) "Effects of Prenatal and Early Life Malnutrition: Evidence from the Greek Famine," Journal of Health Economics, 30(3), 479-488.

Neugebauer R., H. W. Hoek, and E. Susser (1999) "Prenatal Exposure to Wartime Famine and Development of Antisocial Personality Disorder in Adulthood," Journal of the American Medical Association, 281(5), 455-462.

Pembrey, M. E., Bygren, L. O., Kaati, G., Edvinsson, S., Northstone, K., Sjostrom, M., et al. (2006) “Sexspecific, Male-line Transgenerational Responses in Humans," European Journal of Human Genetics, 14, 159-166.

Ravallion, M. (1997) "Famines and Economics," Journal of Economic Literature, 35(3), 1205-1242.

Ravelli, A. C. J., J. H. van de Meulen, and R. P. J. Michels (1998) "Glucose Tolerance in Adults After Prenatal Exposure to Famine," Lancet, 351, 173-177.

Ravelli, A. C. J., J. H. van de Meulen, C. Osmond, D. J. Barker, and O. P. Bleker (1999) "Obesity at the Age of 50 in Men and Women Exposed to Famine Prenatally," American Journal of Clinical Nutrition, $70,811-816$.

Riskin, C. (1990) "Feeding China: the Experience Since 1949," in The Political Economy of Hunger, vol. 3., Jean Dreze, Amartya Sen (Eds.), Oxford University Press, Oxford. 
Roseboom T. J., J. H. P. Meulen, A. C. J. Ravelli, C. Osmond, D. J. P. Barker, and O. P. Bleker (2001) "Effects of Prenatal Exposure to the Dutch Famine on Adult Disease in Later Life: An Overview," Twins Research, 4(5), 293-298.

Stein, Z., M. Susser, G. Saenger, and F. Marolla (1972) "Nutrition and Mental Performance," Science, 179(4062), 708-713.

Skuse, D. H. (2005) “X-linked Genes and Mental Functioning," Human Molecular Genetics, 14, Review Issue 1, R27-R32.

Song, S. (2010) "Mortality Consequences of the 1959-1961 Great Leap Forward Famine in China: Debilitation, Selection, and Mortality Crossovers.” Social Science Medicine, 71(3), 551-8.

Trivers, R. L. and R. E. Willard (1973) "Natural Selection and the Ability to Vary the Sex Ratio of Offspring," Science, 179(4068), 90-92.

Turner, G. (1996) “Intelligence and the X Chromosome," Lancet, 347, 1814-1815.

Wei, S., H. Fang, and B. Gong (2014) "Sex Ratios and Savings Rates: Some Experimental Evidence," working paper.

Yao, S. (1999) “A Note on the Causal Factors of China's Famine in 1959-1961," Journal of Political Economy, 107(6), 1365-1369. 
Figure 1. Transmission of $X$ Chromosome from Parents to Children

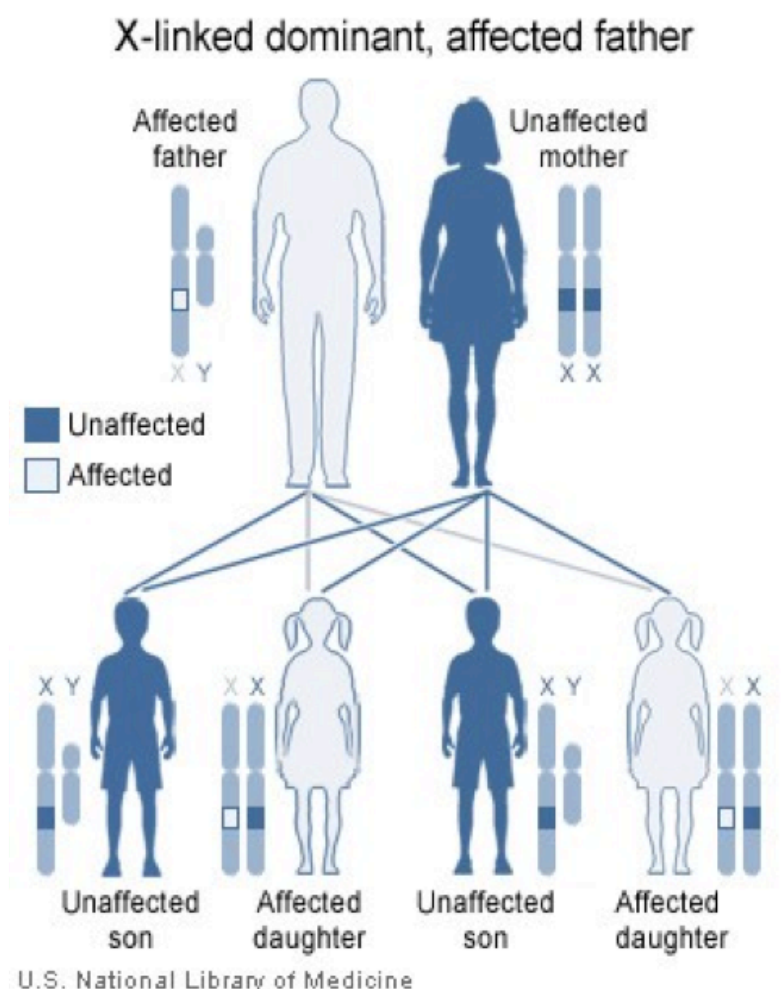

U.S. National Librany of Medicine

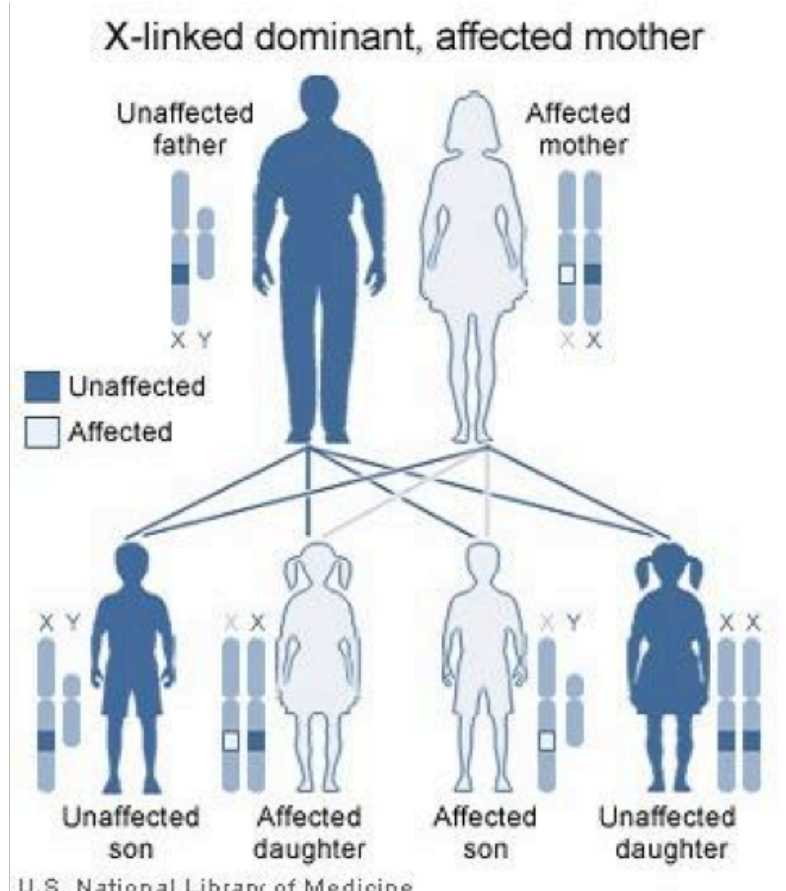


Figure 2. The Math Test Scores for Children of Rural Male Cohort Born in 1953-1965

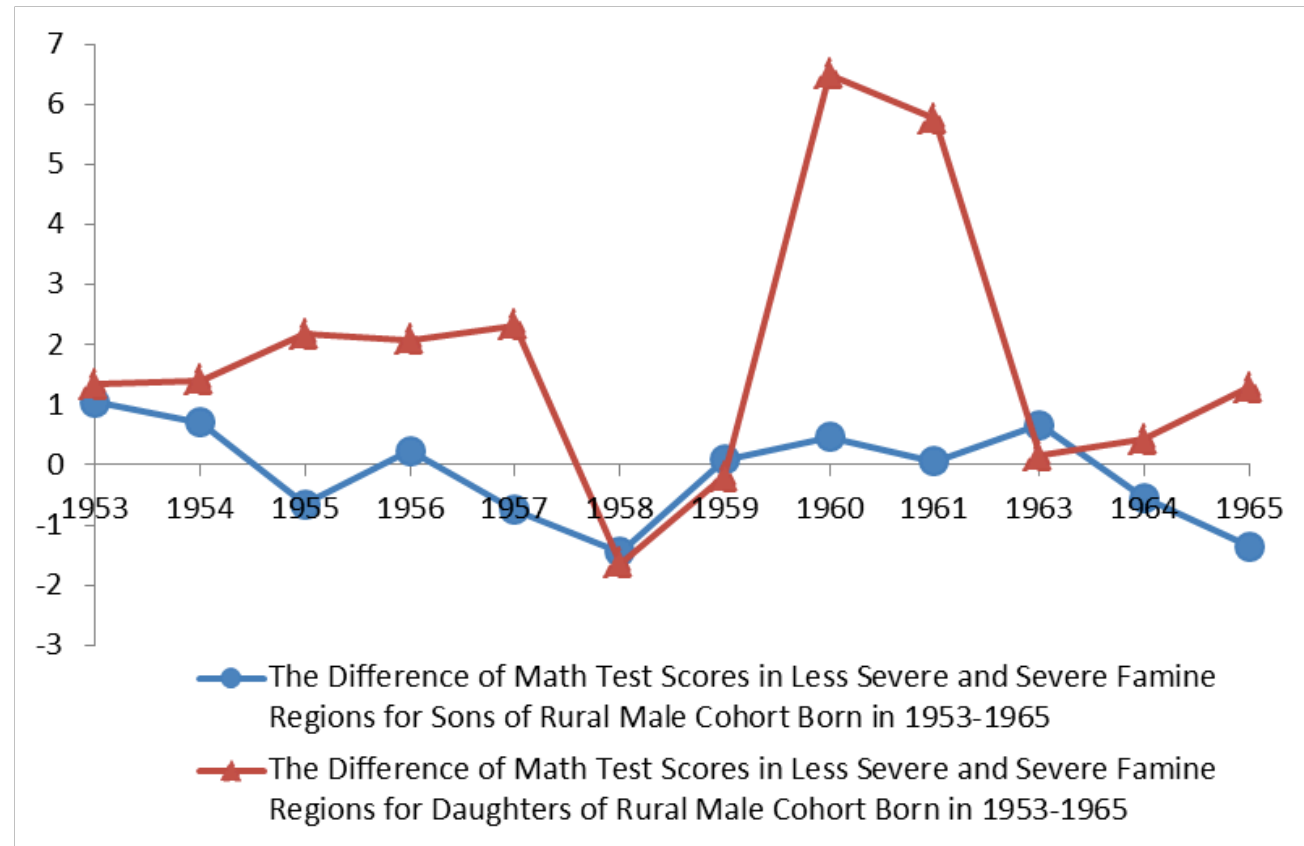

Notes: The severe and less severe groups are categorized by the median value of famine severity variable at the provincial level. Famine severity is measured as the difference between the highest mortality rate at the provincial level during 1959-1961 and average mortality rate during 1956-1958. Horizontal axis refers to fathers' birth year. 
Table 1(a). Summary Statistics of Key Variables

\begin{tabular}{lcccccccc}
\hline & \multicolumn{2}{c}{ All } & & \multicolumn{2}{c}{ Boys } & & \multicolumn{2}{c}{ Girls } \\
\cline { 2 - 3 } \cline { 8 - 9 } \cline { 8 - 9 } Math Test Scores & Mean & Std. & & Mean & Std. & & Mean & Std. \\
Word Test Scores & 15.244 & 5.632 & & 15.194 & 5.810 & & 15.309 & 5.397 \\
Famine & 25.034 & 7.182 & & 24.733 & 7.468 & & 25.425 & 6.780 \\
\hline
\end{tabular}

Table 1(b). Mean of Key Characteristics in Different Groups

\begin{tabular}{lcccc}
\hline & FF-NFM & FM-NFF & FF-FM & NFF-NFM \\
\hline Log family income per capita & $8.69(261)$ & $8.68(225)$ & $8.74(118)$ & $8.76(1112)$ \\
Father's years of education & $7.84(254)$ & $6.89(215)^{* * *}$ & $8.55(114)^{* *}$ & $7.72(1077)$ \\
Mother's years of education & $5.61(263)$ & $5.32(222)$ & $5.72(118)$ & $5.54(1100)$ \\
Spirit drunk last week (50 gram) & $4.80(261)$ & $5.78(225)$ & $5.62(118)$ & $4.24(1110)$ \\
Age of children & $22.32(267)^{* * *}$ & $24.13(226)^{* * *}$ & $23.96(118)^{* * *}$ & $20.87(1117)$ \\
Number of children & $1.59(267)^{* * *}$ & $1.52(226)^{* * *}$ & $1.37(118)$ & $1.29(1117)$ \\
Number of boys & $0.79(267)^{* *}$ & $0.83(226)^{* * *}$ & $0.84(118)^{* *}$ & $0.70(1117)$ \\
Number of girls & $0.85(267)^{* * *}$ & $0.96(226)^{* * *}$ & $0.91(118)^{* * *}$ & $0.69(1117)$ \\
Boys/girls & 0.93 & 0.86 & 0.92 & 1.01 \\
\hline
\end{tabular}

Notes: FF-NFM indicates that father was born during 1959-1961 while mother was not born during 1959-1961. Similar definitions for other acronym. The number in the parenthesis indicates the sample size. $* * *, * *, *$ indicates the mean difference between the corresponding group with the NFF-NFM group is significantly different at $1 \%, 5 \%$ and $10 \%$ level, respectively. 
Table 2. Difference-in-Differences Estimates of the Intergenerational Impact of Famine on Math Scores (Children of Rural Fathers)

\begin{tabular}{lccc}
\hline & \multicolumn{3}{c}{ Level of Famine Severity } \\
\cline { 2 - 4 } & Severe & Less Severe & Difference \\
& $(1)$ & $(2)$ & $(1)-(2)$ \\
\hline & Panel A: All Sample & \\
$1959-1961$ cohort & 13.01 & 14.68 & $-1.67^{* *}$ \\
$1963-1965$ cohort & 15.85 & 15.68 & 0.17 \\
Difference of the above two rows & $-2.84^{* * *}$ & $-1.00^{*}$ & $-1.84^{* *}$ \\
\hline & Panel B: Boys' Sample & \\
$1959-1961$ cohort & 13.58 & 13.83 & -0.25 \\
$1963-1965$ cohort & 16.07 & 15.52 & 0.55 \\
Difference of the above two rows & $-2.49 * * *$ & $-1.69 * *$ & -0.80 \\
\hline & Panel C: Girls' Sample & \\
1959-1961 cohort & 12.23 & 15.82 & $-3.59^{* * *}$ \\
1963-1965 cohort & 15.57 & 15.87 & -0.30 \\
Difference of the above two rows & $-3.34^{* * *}$ & -0.05 & $-3.29^{* * *}$ \\
\hline
\end{tabular}

Sources: China Family Panel Studies (CFPS) survey 2010. We restrict the sample to children whose fathers were born during the Great Famine (1959-1961) and post-famine period (1963-1965) and whose mothers were not born in the famine years.

Notes: Famine severity is measured as the difference between the highest mortality rate at the provincial level during 1959-1961 and average mortality rate during 1956-1958. The severe and less severe famine provinces are defined according to the median value of famine at the provincial level. The severe provinces include Anhui, Guizhou, Sichuan, Qinghai, Gansu, Henan, Hunan, Guangxi, Shandong, Hubei, while the less severe provinces include Liaoning, Yunnan, Jiangsu, Fujian, Guangdong, Hebei, Jilin, Jiangxi, Heilongjiang, Beijing, Zhejiang, Shaanxi, Shanxi, Shanghai, Tianjin. * ${ }^{* *}$, and $* * *$ indicate significance level at $10 \%, 5 \%$ and $1 \%$, respectively. 
Table 3. Intergenerational Impact of Famine on Math Scores for the Children of Rural Fathers: Baseline Results

\begin{tabular}{|c|c|c|c|c|c|c|}
\hline \multicolumn{7}{|c|}{ Dependent Variable: Math Test Scores (the higher the better) } \\
\hline & \multicolumn{2}{|c|}{ All } & \multicolumn{2}{|c|}{ Boys } & \multicolumn{2}{|c|}{ Girls } \\
\hline & (1) & (2) & (3) & (4) & (5) & (6) \\
\hline Famine* & $-0.057^{*}$ & $-0.073^{* *}$ & -0.012 & -0.028 & $-0.097^{* *}$ & $-0.109 * *$ \\
\hline Father born in 1959-1961 & $(0.032)$ & $(0.034)$ & $(0.037)$ & $(0.043)$ & $(0.045)$ & $(0.051)$ \\
\hline \multirow[t]{2}{*}{ Father born in 1959-1961 } & 0.329 & 0.471 & -0.774 & -0.706 & 1.338 & 1.640 \\
\hline & $(0.742)$ & $(0.761)$ & $(0.763)$ & $(0.830)$ & $(1.147)$ & $(1.220)$ \\
\hline \multirow[t]{2}{*}{ Famine } & 0.010 & & 0.022 & & -0.019 & \\
\hline & $(0.025)$ & & $(0.032)$ & & $(0.022)$ & \\
\hline \multirow[t]{2}{*}{ Boy dummy } & $-0.823 *$ & -0.764 & & & & \\
\hline & (0.419) & $(0.471)$ & & & & \\
\hline \multirow[t]{2}{*}{ Age } & $22.808^{* * *}$ & $21.927^{* * *}$ & $23.556^{* *}$ & $23.897^{* *}$ & $20.605^{* * *}$ & $22.193^{* * *}$ \\
\hline & (7.125) & (7.210) & (11.226) & (11.082) & $(6.920)$ & $(7.361)$ \\
\hline \multirow[t]{2}{*}{ Age square } & $-1.024^{* * *}$ & $-0.978 * * *$ & $-1.081^{* *}$ & $-1.093^{* *}$ & $-0.911 * * *$ & $-0.976 * * *$ \\
\hline & $(0.321)$ & $(0.325)$ & $(0.506)$ & (0.499) & $(0.316)$ & $(0.336)$ \\
\hline \multirow[t]{2}{*}{ Age cubic } & $0.015^{* * *}$ & $0.014^{* * *}$ & $0.016^{* *}$ & $0.016^{* *}$ & $0.013^{* *}$ & $0.014 * *$ \\
\hline & $(0.005)$ & $(0.005)$ & $(0.007)$ & $(0.007)$ & $(0.005)$ & $(0.005)$ \\
\hline Father below middle & $-1.901^{* * *}$ & $-1.697 * * *$ & $-1.917^{* * *}$ & $-1.809 * * *$ & $-2.107^{* * *}$ & $-1.745 * * *$ \\
\hline school (dummy) & $(0.401)$ & $(0.394)$ & $(0.492)$ & (0.449) & (0.529) & $(0.581)$ \\
\hline Mother below middle & $-0.809 * *$ & $-0.921 * *$ & $-1.165^{* *}$ & $-1.286^{* *}$ & -0.211 & -0.313 \\
\hline school (dummy) & (0.299) & $(0.332)$ & $(0.475)$ & $(0.513)$ & $(0.368)$ & $(0.436)$ \\
\hline \multirow[t]{2}{*}{ Number of siblings } & $-0.457^{*}$ & -0.471 & -0.476 & -0.631 & $-0.455^{*}$ & -0.359 \\
\hline & $(0.250)$ & $(0.285)$ & $(0.413)$ & $(0.477)$ & $(0.264)$ & $(0.346)$ \\
\hline \multirow[t]{2}{*}{ Birth order } & $-0.985^{* * *}$ & $-0.976 * * *$ & 0.006 & 0.129 & $-1.746 * * *$ & $-1.815^{* * *}$ \\
\hline & $(0.308)$ & $(0.297)$ & $(0.343)$ & $(0.302)$ & $(0.390)$ & $(0.374)$ \\
\hline Time to nearest & 0.085 & -0.087 & 0.348 & 0.218 & -0.033 & -0.317 \\
\hline hospital (log) & $(0.223)$ & $(0.162)$ & $(0.273)$ & $(0.238)$ & $(0.284)$ & $(0.249)$ \\
\hline Distance to nearest & $-0.335^{* *}$ & $-0.313^{* *}$ & $-0.434 * *$ & $-0.413^{* *}$ & -0.122 & -0.025 \\
\hline high school (log) & $(0.135)$ & (0.129) & $(0.204)$ & $(0.198)$ & $(0.231)$ & $(0.214)$ \\
\hline Family income per & $0.571 * * *$ & $0.450^{* *}$ & $0.579 * *$ & $0.488^{*}$ & $0.545^{*}$ & 0.346 \\
\hline person (log) & $(0.185)$ & $(0.181)$ & $(0.265)$ & (0.259) & $(0.294)$ & $(0.284)$ \\
\hline \multirow[t]{2}{*}{ Log height } & $11.885^{* * *}$ & $12.190 * * *$ & $20.320 * *$ & $23.270 * * *$ & $8.080^{* *}$ & $8.664^{* *}$ \\
\hline & (3.659) & $(3.807)$ & (8.738) & (7.184) & (3.056) & (3.243) \\
\hline \multirow[t]{2}{*}{ Log weight } & -0.791 & -0.938 & 0.062 & -0.130 & -2.070 & -2.293 \\
\hline & $(1.024)$ & $(1.140)$ & (1.094) & (1.301) & (1.565) & $(1.786)$ \\
\hline \multirow[t]{2}{*}{ In good health (dummy) } & 1.282 & 1.391 & $3.188^{*}$ & $3.430 * *$ & -1.468 & -1.397 \\
\hline & (1.107) & (1.146) & (1.599) & (1.641) & $(1.077)$ & $(1.148)$ \\
\hline Province dummies & No & Yes & No & Yes & No & Yes \\
\hline Observations & 968 & 968 & 547 & 547 & 421 & 421 \\
\hline Adjusted $R^{2}$ & 0.207 & 0.227 & 0.214 & 0.241 & 0.248 & 0.264 \\
\hline AIC & 5884.9 & 5837.3 & 3366.1 & 3321.0 & 2510.5 & 2471.3 \\
\hline
\end{tabular}

Notes: Ethnicity fixed effects are controlled in all the regressions. Due to space limit, they are not reported. The variable "Fathers below middle school" indicates that father's education level is primary school or below. "In good health" is a subjective evaluation of respondent, which equals 1 if the health status is pretty good or good and 0 otherwise. Robust standard errors clustered at the province level are in parenthesis. $*, * *$, and $* * *$ indicate significance level at $10 \%, 5 \%$ and $1 \%$, respectively. 
Table 4. Intergenerational Impact of Famine on Math Scores for the Children of Rural Fathers Born in 1953-1958: No Trend in the Pre-famine Period

\begin{tabular}{|c|c|c|c|c|c|c|}
\hline \multicolumn{7}{|c|}{ Dependent Variable: Math Test Scores (the higher the better) } \\
\hline & \multicolumn{2}{|c|}{ All } & \multicolumn{2}{|c|}{ Boys } & \multicolumn{2}{|c|}{ Girls } \\
\hline & (1) & $(2)$ & (3) & (4) & (5) & (6) \\
\hline \multirow[t]{2}{*}{ Famine* Cohort 1953} & -0.033 & -0.023 & -0.028 & -0.024 & -0.083 & -0.047 \\
\hline & $(0.060)$ & $(0.069)$ & $(0.059)$ & $(0.068)$ & $(0.120)$ & $(0.123)$ \\
\hline \multirow[t]{2}{*}{ Famine* Cohort 1954} & -0.032 & -0.011 & -0.019 & -0.008 & -0.114 & -0.074 \\
\hline & $(0.069)$ & $(0.079)$ & $(0.063)$ & $(0.077)$ & $(0.127)$ & $(0.143)$ \\
\hline \multirow[t]{2}{*}{ Famine* Cohort 1955} & 0.015 & 0.010 & 0.037 & 0.029 & -0.034 & -0.014 \\
\hline & $(0.058)$ & $(0.065)$ & $(0.048)$ & $(0.062)$ & (0.114) & $(0.121)$ \\
\hline \multirow[t]{2}{*}{ Famine* Cohort 1956} & -0.029 & -0.000 & -0.042 & -0.020 & -0.070 & -0.028 \\
\hline & $(0.068)$ & $(0.068)$ & $(0.062)$ & $(0.062)$ & (0.138) & $(0.144)$ \\
\hline \multirow[t]{2}{*}{ Famine* Cohort 1957} & -0.024 & -0.027 & -0.022 & -0.040 & -0.056 & -0.049 \\
\hline & $(0.062)$ & $(0.069)$ & $(0.063)$ & $(0.066)$ & $(0.102)$ & $(0.115)$ \\
\hline \multirow[t]{2}{*}{ Famine* Cohort 1958} & 0.081 & 0.087 & 0.059 & 0.068 & 0.071 & 0.077 \\
\hline & $(0.067)$ & $(0.066)$ & $(0.094)$ & $(0.093)$ & (0.098) & $(0.105)$ \\
\hline \multirow[t]{2}{*}{ Cohort 1953} & 1.237 & 1.069 & 1.286 & 1.356 & 1.647 & 0.779 \\
\hline & (1.699) & $(1.905)$ & (1.524) & $(1.674)$ & (2.496) & $(2.681)$ \\
\hline \multirow[t]{2}{*}{ Cohort 1954} & 0.887 & 0.780 & 1.332 & 1.513 & 1.056 & 0.237 \\
\hline & $(1.285)$ & $(1.372)$ & $(1.065)$ & $(1.176)$ & (2.039) & $(2.270)$ \\
\hline \multirow[t]{2}{*}{ Cohort 1955} & -0.623 & -0.348 & -0.820 & -0.255 & -0.023 & -0.050 \\
\hline & $(1.297)$ & $(1.385)$ & (1.121) & $(1.350)$ & (1.794) & $(1.891)$ \\
\hline \multirow[t]{2}{*}{ Cohort 1956} & 0.843 & 0.293 & 1.140 & 0.908 & 1.382 & 0.574 \\
\hline & (1.158) & $(1.078)$ & (1.101) & $(1.068)$ & (1.718) & (1.728) \\
\hline \multirow[t]{2}{*}{ Cohort 1957} & -0.012 & 0.245 & 0.028 & 0.619 & 0.346 & 0.252 \\
\hline & $(1.251)$ & $(1.326)$ & (1.512) & (1.513) & (1.706) & (1.815) \\
\hline \multirow[t]{2}{*}{ Cohort 1958} & -0.533 & -0.565 & -0.148 & -0.273 & -0.211 & -0.233 \\
\hline & $(0.746)$ & $(0.711)$ & (1.009) & $(1.070)$ & (1.126) & (1.227) \\
\hline \multirow[t]{2}{*}{ Famine } & 0.021 & & 0.044 & & 0.031 & \\
\hline & $(0.047)$ & & $(0.045)$ & & $(0.102)$ & \\
\hline Other controls & Yes & Yes & Yes & Yes & Yes & Yes \\
\hline Province dummies & No & Yes & No & Yes & No & Yes \\
\hline Observations & 999 & 999 & 586 & 586 & 413 & 413 \\
\hline Adjusted $R^{2}$ & 0.185 & 0.212 & 0.143 & 0.193 & 0.250 & 0.267 \\
\hline AIC & 6033.3 & 5971.1 & 3525.7 & 3466.4 & 2507.1 & 2467.4 \\
\hline
\end{tabular}

Notes: The table tests whether the difference in math test scores between different areas and cohorts already exists before the famine. The cohort 1959 is used as the base group. See the notes in Table 3 for the definition of the famine severity variable. The control variables, which are the same as those in Table 3, are included but not reported here. Robust standard errors clustered at the province level are in parenthesis. $*, * *$, and $* * *$ indicate significance level at $10 \%, 5 \%$ and $1 \%$, respectively. 
Table 5. Robustness Check: Using Changes in County-Level Cohort Size as a Measure for the Famine Severity

\begin{tabular}{|c|c|c|c|c|c|c|}
\hline \multicolumn{7}{|c|}{ Dependent Variable: Math Test Score (the higher the better) } \\
\hline & \multicolumn{2}{|c|}{ All } & \multicolumn{2}{|c|}{ Boys } & \multicolumn{2}{|c|}{ Girls } \\
\hline & $(1)$ & $(2)$ & (3) & (4) & (5) & (6) \\
\hline Famine* & $-4.053^{*}$ & $-3.732 *$ & -0.013 & -2.026 & $-8.269 * *$ & $-5.929 *$ \\
\hline Cohort 1959-1961 & $(2.555)$ & $(2.152)$ & $(3.230)$ & $(3.414)$ & $(3.670)$ & $(3.571)$ \\
\hline \multirow[t]{2}{*}{ Cohort 1959-1961 } & 0.639 & 0.461 & -1.009 & -0.577 & $2.505^{*}$ & 1.840 \\
\hline & $(0.985)$ & $(0.884)$ & $(1.099)$ & (1.091) & $(1.380)$ & $(1.470)$ \\
\hline \multirow[t]{2}{*}{ Famine } & 0.811 & & -0.817 & & 2.194 & \\
\hline & $(1.585)$ & & $(1.728)$ & & $(1.969)$ & \\
\hline \multirow[t]{2}{*}{ Boy dummy } & $-0.821 *$ & $-0.786 *$ & & & & \\
\hline & $(0.419)$ & $(0.461)$ & & & & \\
\hline Other controls & Yes & Yes & Yes & Yes & Yes & Yes \\
\hline County dummies & No & Yes & No & Yes & No & Yes \\
\hline Observations & 968 & 968 & 547 & 547 & 421 & 421 \\
\hline Adjusted $R^{2}$ & 0.206 & 0.225 & 0.212 & 0.241 & 0.241 & 0.259 \\
\hline AIC & 5887.9 & 5842.4 & 3365.0 & 3319.0 & 2512.5 & 2474.0 \\
\hline
\end{tabular}

Notes: Famine=(Cohort size in 1956-1958-cohort size in 1959-1961)/cohort size in 1956-1958. Cohort size is from $20001 \%$ population census. Massive migration did not take place until the late 1990s. Even at the time, most of the migrants were younger than 30 years old. Ethnicity fixed effects are controlled in all regressions. Due to space limit, they are not reported. The dummy variable "Cohort 1959-1961" indicates children whose fathers were born during 1959-1961. The same set of control variables as in Table 3 are included but not reported. Robust standard errors clustered at the county level are in parenthesis. ${ }^{*}, * *$, and ${ }^{* * *}$ indicate significance level at $10 \%, 5 \%$ and $1 \%$, respectively. 
Table 6. Additional Robustness Check: Dropping Migrants from the Rural Sample

\begin{tabular}{|c|c|c|c|c|c|c|}
\hline \multicolumn{7}{|c|}{ Dependent Variable: Math Test Scores (the higher the better) } \\
\hline & \multicolumn{2}{|c|}{ All } & \multicolumn{2}{|c|}{ Boys } & \multicolumn{2}{|c|}{ Girls } \\
\hline & (1) & (2) & (3) & (4) & (5) & (6) \\
\hline Famine* & $-0.058^{*}$ & $-0.074^{* *}$ & -0.019 & -0.041 & $-0.096 *$ & $-0.097^{*}$ \\
\hline Cohort 1959-1961 & $(0.033)$ & $(0.035)$ & $(0.040)$ & $(0.042)$ & $(0.051)$ & $(0.057)$ \\
\hline \multirow[t]{2}{*}{ Cohort 1959-1961 } & 0.320 & 0.477 & -0.645 & -0.489 & 1.214 & 1.314 \\
\hline & $(0.723)$ & $(0.744)$ & $(0.810)$ & $(0.876)$ & $(1.113)$ & $(1.197)$ \\
\hline \multirow[t]{2}{*}{ Famine } & 0.008 & & 0.029 & & -0.031 & \\
\hline & $(0.025)$ & & $(0.033)$ & & $(0.023)$ & \\
\hline \multirow[t]{2}{*}{ Boy dummy } & $-0.969 *$ & $-1.055^{*}$ & & & & \\
\hline & $(0.521)$ & $(0.535)$ & & & & \\
\hline Other controls & Yes & Yes & Yes & Yes & Yes & Yes \\
\hline Province dummies & No & Yes & No & Yes & No & Yes \\
\hline Observations & 920 & 920 & 522 & 522 & 398 & 398 \\
\hline Adjusted $R^{2}$ & 0.212 & 0.229 & 0.217 & 0.241 & 0.258 & 0.267 \\
\hline AIC & 5583.1 & 5535.7 & 3213.2 & 3167.0 & 2357.3 & 2322.1 \\
\hline
\end{tabular}

Notes: We drop observations whose living place is different from the birth place. See the notes in Table 2 for the definition of the famine severity variable. Ethnicity fixed effects are controlled in all regressions. Due to space limit, they are not reported. The dummy variable "Cohort 1959-1961" indicates children whose fathers were born during 1959-1961. The same set of control variables as those in Table 3 are included but not reported. Robust standard errors clustered at the county level are in parenthesis. ${ }^{*}, * *$, and ${ }^{* * *}$ indicate significance level at $10 \%, 5 \%$ and $1 \%$, respectively. 
Table 7. Falsification Test

\begin{tabular}{|c|c|c|c|c|c|c|}
\hline \multicolumn{7}{|c|}{ Dependent Variable: Math Test Score (the higher the better) } \\
\hline & \multicolumn{2}{|c|}{ All } & \multicolumn{2}{|c|}{ Boys } & \multicolumn{2}{|c|}{ Girls } \\
\hline & (1) & $(2)$ & (3) & (4) & (5) & (6) \\
\hline \multicolumn{7}{|c|}{ Panel A: Children of Male Cohort Born in 1959-1961 and 1963-1965 in Cities } \\
\hline Famine* & -0.074 & -0.058 & -0.100 & -0.125 & -0.065 & -0.060 \\
\hline Cohort 1959-1961 & $(0.055)$ & $(0.061)$ & $(0.064)$ & $(0.082)$ & $(0.058)$ & $(0.063)$ \\
\hline \multirow[t]{2}{*}{ Cohort 1959-1961 } & 1.094 & 0.840 & 1.491 & 1.420 & 0.558 & 0.679 \\
\hline & $(0.642)$ & $(0.657)$ & $(0.972)$ & $(0.925)$ & $(0.559)$ & (0.603) \\
\hline \multirow[t]{2}{*}{ Famine } & 0.017 & & 0.027 & & 0.017 & \\
\hline & (0.029) & & $(0.042)$ & & $(0.016)$ & \\
\hline \multirow[t]{2}{*}{ Boy dummy } & -0.702 & -0.358 & & & & \\
\hline & (0.959) & (1.099) & & & & \\
\hline Other controls & Yes & Yes & Yes & Yes & Yes & Yes \\
\hline Province dummies & No & Yes & No & Yes & No & Yes \\
\hline Observations & 259 & 259 & 125 & 125 & 134 & 134 \\
\hline Adjusted $R^{2}$ & 0.230 & 0.243 & 0.275 & 0.434 & 0.100 & 0.053 \\
\hline AIC & 1373.2 & 1339.4 & 684.6 & 623.6 & 703.9 & 680.9 \\
\hline \multicolumn{7}{|c|}{ Panel B: Children of Rural Male Cohort Born in 1963-1965 and 1966-1968 } \\
\hline Famine* & -0.021 & -0.023 & -0.012 & -0.012 & -0.047 & -0.043 \\
\hline Cohort 1963-1965 & $(0.023)$ & $(0.023)$ & $(0.034)$ & $(0.038)$ & $(0.027)$ & $(0.026)$ \\
\hline \multirow[t]{2}{*}{ Cohort 1963-1965 } & 0.633 & 0.535 & 1.022 & 1.150 & 0.271 & 0.200 \\
\hline & $(0.530)$ & $(0.522)$ & (0.659) & $(0.752)$ & $(0.630)$ & $(0.537)$ \\
\hline \multirow[t]{2}{*}{ Famine } & 0.027 & & 0.038 & & 0.021 & \\
\hline & (0.016) & & $(0.026)$ & & $(0.017)$ & \\
\hline \multirow[t]{2}{*}{ Boy dummy } & -0.594 & -0.421 & & & & \\
\hline & (0.553) & $(0.566)$ & & & & \\
\hline Province dummies & No & Yes & No & Yes & No & Yes \\
\hline Observations & 1321 & 1321 & 714 & 714 & 607 & 607 \\
\hline Adjusted $R^{2}$ & 0.173 & 0.204 & 0.135 & 0.186 & 0.247 & 0.258 \\
\hline AIC & 7823.8 & 7917.9 & 4380.2 & 4312.1 & 3604.6 & 3566.1 \\
\hline
\end{tabular}

Notes: Ethnicity fixed effects are controlled in all regressions. Due to space limit, they are not reported. Cohort 1959-1961 (dummy) indicates children whose father was born during 1959-1961. Cohort 1963-1965 (dummy) indicates children whose father was born during 1963-1965. Other controls same as those in Table 3 are included but not reported here. Robust standard errors clustered at the province level are in parenthesis. ${ }^{*},{ }^{* *}$, and ${ }^{* * *}$ indicate significance level at $10 \%, 5 \%$ and $1 \%$, respectively. 
Table 8(a). The Intergenerational Impact of Famine on Math Test Scores (Rural Fathers to Children): First Stage Results

\begin{tabular}{|c|c|c|c|c|c|c|c|c|c|}
\hline \multirow[b]{3}{*}{ Dependent Variable } & \multicolumn{3}{|c|}{ All } & \multicolumn{3}{|c|}{ Boys } & \multicolumn{3}{|c|}{ Girls } \\
\hline & (1) & (2) & (3) & (4) & (5) & (6) & (7) & (8) & (9) \\
\hline & $\begin{array}{c}\text { Famine* } \\
\text { Cohort 1959- } \\
1961\end{array}$ & Famine & $\begin{array}{c}\text { Famine* } \\
\text { Cohort 1959- } \\
1961\end{array}$ & $\begin{array}{c}\text { Famine* } \\
\text { Cohort 1959- } \\
1961 \\
\end{array}$ & Famine & $\begin{array}{c}\text { Famine* } \\
\text { Cohort 1959- } \\
1961\end{array}$ & $\begin{array}{c}\text { Famine* } \\
\text { Cohort 1959- } \\
1961\end{array}$ & Famine & $\begin{array}{c}\text { Famine* }^{*} \\
\text { Cohort 1959- } \\
1961 \\
\end{array}$ \\
\hline Governor birth place* & $7.184^{* * *}$ & $-4.531 * *$ & $6.995 * * *$ & $7.412^{* * *}$ & -2.596 & $7.463^{* * *}$ & $6.528^{* * *}$ & $-7.164^{* *}$ & $6.340^{* * *}$ \\
\hline Cohort 1959-1961 & (1.596) & (2.094) & (1.587) & (1.698) & $(2.268)$ & (1.649) & (1.894) & (3.159) & (1.879) \\
\hline Secretary birth place* & 2.625 & 1.171 & 2.751 & 1.730 & -1.321 & 2.518 & 4.184 & 5.033 & 3.764 \\
\hline Cohort 1959-1961 & (7.727) & (2.675) & (7.733) & $(7.852)$ & (2.538) & (7.799) & (7.439) & (3.649) & (7.794) \\
\hline \multirow[t]{2}{*}{ Governor birth place } & -0.049 & $12.165^{* *}$ & & 0.149 & $12.066^{* *}$ & & -0.312 & $12.739 * *$ & \\
\hline & $(0.443)$ & $(5.090)$ & & $(0.478)$ & $(4.803)$ & & $(0.446)$ & $(5.431)$ & \\
\hline \multirow[t]{2}{*}{ Secretary birth place } & 0.158 & 1.545 & & 0.243 & 2.520 & & 0.150 & -0.370 & \\
\hline & $(0.416)$ & (7.423) & & $(0.543)$ & (7.044) & & $(0.292)$ & (8.254) & \\
\hline \multirow[t]{2}{*}{ Cohort 1959-1961 } & 8.111 & 0.505 & $8.920^{*}$ & $8.931^{*}$ & 0.037 & $9.308^{*}$ & 7.282 & 0.854 & $8.284^{*}$ \\
\hline & (5.363) & (0.529) & (5.518) & (5.459) & (1.364) & (5.424) & (5.306) & (1.183) & (5.703) \\
\hline \multirow[t]{2}{*}{ Boy dummy } & 0.147 & -0.205 & 0.117 & & & & & & \\
\hline & $(0.528)$ & $(1.090)$ & $(0.373)$ & & & & & & \\
\hline Province dummies & No & No & Yes & No & No & Yes & No & No & Yes \\
\hline Observations & 968 & 968 & 968 & 547 & 547 & 547 & 421 & 421 & 421 \\
\hline Adjusted $R^{2}$ & 0.58 & 0.69 & 0.69 & 0.57 & 0.71 & 0.69 & 0.59 & 0.68 & 0.70 \\
\hline
\end{tabular}


Table 8(b). The Intergenerational Impact of Famine on Math Test Scores (Rural Fathers to Children): 2SLS Regressions

\begin{tabular}{|c|c|c|c|c|c|c|}
\hline \multicolumn{7}{|c|}{ Dependent Variable: Math Test Score (the higher the better) } \\
\hline & \multicolumn{2}{|c|}{ All } & \multicolumn{2}{|c|}{ Boys } & \multicolumn{2}{|c|}{ Girls } \\
\hline & (1) & $(2)$ & (3) & $(4)$ & $(5)$ & (6) \\
\hline Famine* & $-0.251^{* *}$ & $-0.239 *$ & -0.165 & -0.189 & $-0.390 * *$ & $-0.321^{* *}$ \\
\hline Cohort 1959-1961 & $(0.127)$ & $(0.133)$ & $(0.138)$ & $(0.141)$ & $(0.198)$ & $(0.164)$ \\
\hline \multirow[t]{2}{*}{ Cohort 1959-1961 } & $3.206^{*}$ & 2.863 & 1.781 & 1.733 & $5.074 * *$ & $4.481^{* *}$ \\
\hline & $(1.897)$ & $(1.940)$ & $(2.294)$ & $(2.247)$ & $(2.284)$ & $(1.953)$ \\
\hline \multirow[t]{2}{*}{ Famine } & 0.072 & & $0.148^{*}$ & & -0.029 & \\
\hline & $(0.076)$ & & $(0.086)$ & & $(0.073)$ & \\
\hline \multirow[t]{2}{*}{ Boy dummy } & $-0.792 *$ & -0.745 & & & & \\
\hline & $(0.438)$ & $(0.471)$ & & & & \\
\hline Province dummies & No & Yes & No & Yes & No & Yes \\
\hline Hausman-Wu Statistics & 2.35 & $2.83^{*}$ & 2.10 & 2.21 & $3.80 * *$ & 2.72 \\
\hline Cragg-Donald Wald F & $26.91^{+}$ & $54.29^{+}$ & $15.39^{-}$ & $30.81^{+}$ & $12.09^{-}$ & $25.07^{+}$ \\
\hline Hansen J Statistics & 4.05 & 0.11 & 1.32 & 0.21 & 4.29 & 0.02 \\
\hline Observations & 968 & 968 & 547 & 547 & 421 & 421 \\
\hline Adjusted $R^{2}$ & 0.202 & 0.225 & 0.187 & 0.239 & 0.232 & 0.261 \\
\hline
\end{tabular}

Notes: Provincial governor's birthplace and provincial secretary's birthplace are used as instrumental variables. Provincial governor's birthplace equals 1 if the province he was in charge during famine period happens to be his birth province and 0 otherwise. The definition for provincial secretary's birthplace is similar. The same control variables as those in Table 3 are included but not reported. Robust standard errors clustered at the province level are in parenthesis. $* * *$, and $* * *$ indicate significance level at $10 \%, 5 \%$ and $1 \%$, respectively. + indicates that the statistics is larger than the threshold of $r=0.10$ and significance level at $5 \%$, and - indicates that the statistics is larger than the threshold of $r=0.15$ but smaller than the threshold of $r=0.10$ and significance level at $5 \%$, tabulated by table 2 of Stock and Yogo (2002). 
Table 9. The Intergenerational Impact (Rural Fathers to Children) of Famine on Math Test Scores: Quantile Regressions

\begin{tabular}{|c|c|c|c|c|c|c|c|c|c|}
\hline \multicolumn{10}{|c|}{ Dependent variable: Math test score (the higher, the better) } \\
\hline & (1) & (2) & (3) & (4) & (5) & (6) & (7) & (8) & (9) \\
\hline Quantile & 0.1 & 0.2 & 0.3 & 0.4 & 0.5 & 0.6 & 0.7 & 0.8 & 0.9 \\
\hline \multicolumn{10}{|c|}{ Whole Sample } \\
\hline Famine* & -0.039 & -0.050 & $-0.080^{*}$ & $-0.052^{* *}$ & -0.048 & $-0.062^{*}$ & $-0.071^{* *}$ & $-0.084 * * *$ & -0.047 \\
\hline Cohort 1959-1961 & (0.059) & $(0.042)$ & $(0.042)$ & $(0.025)$ & $(0.038)$ & $(0.038)$ & $(0.035)$ & $(0.029)$ & $(0.036)$ \\
\hline Other controls & Yes & Yes & Yes & Yes & Yes & Yes & Yes & Yes & Yes \\
\hline Observations & 968 & 968 & 968 & 968 & 968 & 968 & 968 & 968 & 968 \\
\hline \multicolumn{10}{|c|}{ Boys' Sample } \\
\hline Famine* & $0.102^{*}$ & 0.002 & 0.021 & 0.007 & -0.030 & -0.027 & -0.043 & -0.050 & -0.033 \\
\hline Cohort 1959-1961 & $(0.060)$ & $(0.073)$ & $(0.086)$ & $(0.053)$ & $(0.042)$ & $(0.042)$ & $(0.073)$ & $(0.063)$ & $(0.054)$ \\
\hline Other controls & Yes & Yes & Yes & Yes & Yes & Yes & Yes & Yes & Yes \\
\hline Observations & 547 & 547 & 547 & 547 & 547 & 547 & 547 & 547 & 547 \\
\hline \multicolumn{10}{|c|}{ Girls' Sample } \\
\hline Famine* & -0.063 & -0.060 & $-0.080 * *$ & -0.117 & $-0.138^{*}$ & $-0.108^{* *}$ & $-0.076^{* * *}$ & -0.067 & $-0.148 * * *$ \\
\hline Cohort 1959-1961 & $(0.087)$ & $(0.059)$ & $(0.041)$ & $(0.079)$ & $(0.076)$ & $(0.054)$ & $(0.026)$ & (0.119) & $(0.053)$ \\
\hline Other controls & Yes & Yes & Yes & Yes & Yes & Yes & Yes & Yes & Yes \\
\hline Observations & 421 & 421 & 421 & 421 & 421 & 421 & 421 & 421 & 421 \\
\hline
\end{tabular}

Notes: We report the results based on the specification of column (1) of table 3 . See the notes in Table 2 for the definition of the famine severity variable. Ethnicity fixed effects are controlled in all regressions. Due to space limit, they are not reported. The dummy variable "Cohort 1959-1961" indicates children whose fathers were born during $1959-1961$. The same set of control variables as in Table 3 are included but not reported. Robust standard errors clustered at the province level are in parenthesis. ${ }^{*}, * *$, and $* * *$ indicate significance level at $10 \%, 5 \%$ and $1 \%$, respectively. 
Table 10. Impact of Famine on Math Test Scores of Rural Famine Survivors in Different Samples

\begin{tabular}{|c|c|c|c|c|c|c|}
\hline \multicolumn{7}{|c|}{ Dependent Variable: Math Test Scores (the higher the better) } \\
\hline & \multicolumn{2}{|c|}{ All } & \multicolumn{2}{|c|}{ Males } & \multicolumn{2}{|c|}{ Females } \\
\hline & (1) & (2) & (3) & (4) & (5) & (6) \\
\hline \multicolumn{7}{|c|}{ Panel A: All Famine Survivors } \\
\hline \multirow[t]{2}{*}{ Famine*Born in 1959-1961 } & -0.018 & -0.017 & 0.002 & 0.000 & $-0.046 * * *$ & $-0.037 * * *$ \\
\hline & $(0.011)$ & $(0.010)$ & $(0.016)$ & $(0.017)$ & $(0.011)$ & $(0.008)$ \\
\hline \multirow[t]{2}{*}{ Born in 1959-1961 } & 1.318 & 1.046 & 1.380 & 0.965 & 1.587 & 1.207 \\
\hline & $(0.816)$ & $(0.797)$ & $(0.964)$ & $(0.956)$ & $(0.953)$ & $(0.922)$ \\
\hline \multirow[t]{2}{*}{ Famine } & 0.005 & & 0.004 & & 0.007 & \\
\hline & $(0.006)$ & & $(0.007)$ & & $(0.010)$ & \\
\hline \multirow[t]{2}{*}{ Male dummy } & $0.677 * * *$ & $0.672 * * *$ & & & & \\
\hline & $(0.204)$ & $(0.186)$ & & & & \\
\hline Province dummies & No & Yes & No & Yes & No & Yes \\
\hline Observations & 2951 & 2951 & 1469 & 1469 & 1482 & 1482 \\
\hline Adjusted $R^{2}$ & 0.731 & 0.735 & 0.684 & 0.691 & 0.745 & 0.752 \\
\hline AIC & 15144.3 & 15081.5 & 7579.3 & 7516.8 & 7564.5 & 7501.2 \\
\hline \multicolumn{7}{|c|}{ Panel B: Married Famine Survivors } \\
\hline \multirow[t]{2}{*}{ Famine*Born in 1959-1961 } & -0.018 & -0.017 & 0.004 & 0.003 & $-0.049 * * *$ & $-0.038 * * *$ \\
\hline & $(0.012)$ & (0.011) & $(0.018)$ & $(0.018)$ & $(0.011)$ & $(0.009)$ \\
\hline \multirow[t]{2}{*}{ Born in 1959-1961 } & 1.239 & 0.918 & 0.921 & 0.507 & $1.938^{*}$ & 1.496 \\
\hline & $(0.832)$ & $(0.803)$ & $(1.025)$ & (1.018) & $(0.970)$ & $(0.933)$ \\
\hline \multirow[t]{2}{*}{ Famine } & 0.005 & & 0.003 & & 0.009 & \\
\hline & $(0.006)$ & & $(0.007)$ & & $(0.010)$ & \\
\hline \multirow[t]{2}{*}{ Male dummy } & $0.662 * * *$ & $0.665 * * *$ & & & & \\
\hline & $(0.191)$ & $(0.171)$ & & & & \\
\hline Province dummies & No & Yes & No & Yes & No & Yes \\
\hline Observations & 2819 & 2819 & 1407 & 1407 & 1412 & 1412 \\
\hline Adjusted $R^{2}$ & 0.728 & 0.733 & 0.678 & 0.685 & 0.744 & 0.751 \\
\hline AIC & 14495.7 & 14426.0 & 7257.9 & 7199.5 & 7228.8 & 7164.1 \\
\hline
\end{tabular}

Notes: Ethnicity fixed effects and same control variables as those in baseline regressions are included. Due to space limit, they are not reported. Robust standard errors clustered at the province level are in parenthesis. *, $* *$, and $* * *$ indicate significance level at $10 \%, 5 \%$ and $1 \%$, respectively. 
Table 10 (cont.). Impact of Famine on Math Test Scores of Rural Famine Survivors in Different Samples

\begin{tabular}{|c|c|c|c|c|c|c|}
\hline \multicolumn{7}{|c|}{ Dependent Variable: Math Test Scores (the higher the better) } \\
\hline & \multicolumn{2}{|c|}{ All } & \multicolumn{2}{|c|}{ Males } & \multicolumn{2}{|c|}{ Females } \\
\hline & (1) & $(2)$ & (3) & $(4)$ & (5) & (6) \\
\hline \multicolumn{7}{|c|}{ Panel C: Married Famine Survivors with Children } \\
\hline \multirow[t]{2}{*}{ Famine*Born in 1959-1961 } & -0.018 & -0.017 & 0.004 & 0.004 & $-0.050 * * *$ & $-0.038^{* * *}$ \\
\hline & $(0.012)$ & $(0.011)$ & $(0.018)$ & (0.018) & $(0.012)$ & $(0.010)$ \\
\hline \multirow[t]{2}{*}{ Born in 1959-1961 } & 1.304 & 0.969 & 1.019 & 0.578 & $1.981^{*}$ & 1.512 \\
\hline & (0.839) & $(0.810)$ & $(1.068)$ & $(1.061)$ & $(0.987)$ & $(0.954)$ \\
\hline \multirow[t]{2}{*}{ Famine } & 0.005 & & 0.002 & & 0.009 & \\
\hline & $(0.006)$ & & $(0.007)$ & & $(0.010)$ & \\
\hline \multirow[t]{2}{*}{ Male dummy } & $0.655^{* * *}$ & $0.655^{* * *}$ & & & & \\
\hline & (0.198) & $(0.180)$ & & & & \\
\hline Province dummies & No & Yes & No & Yes & No & Yes \\
\hline Observations & 2799 & 2799 & 1395 & 1395 & 1404 & 1404 \\
\hline Adjusted $R^{2}$ & 0.728 & 0.733 & 0.677 & 0.684 & 0.744 & 0.751 \\
\hline AIC & 14397.9 & 14326.6 & 7194.3 & 7136.3 & 7189.2 & 7117.3 \\
\hline \multicolumn{7}{|c|}{ Panel D: Married Famine Survivors whose Children Took the Test } \\
\hline \multirow[t]{2}{*}{ Famine*Born in 1959-1961 } & $-0.034^{*}$ & $-0.037^{*}$ & -0.017 & -0.022 & $-0.047^{*}$ & $-0.042^{*}$ \\
\hline & (0.019) & (0.019) & $(0.024)$ & (0.026) & $(0.027)$ & $(0.025)$ \\
\hline \multirow[t]{2}{*}{ Born in 1959-1961 } & 1.490 & 1.184 & 1.796 & 1.318 & 1.462 & 0.964 \\
\hline & (0.933) & (0.891) & $(1.118)$ & $(1.170)$ & (1.298) & $(1.318)$ \\
\hline \multirow[t]{2}{*}{ Famine } & 0.005 & & -0.001 & & 0.010 & \\
\hline & $(0.010)$ & & $(0.011)$ & & $(0.014)$ & \\
\hline \multirow[t]{2}{*}{ Male dummy } & $0.767^{* * *}$ & $0.769 * * *$ & & & & \\
\hline & $(0.217)$ & $(0.225)$ & & & & \\
\hline Province dummies & No & Yes & No & Yes & No & Yes \\
\hline Observations & 1707 & 1707 & 870 & 870 & 837 & 837 \\
\hline Adjusted $R^{2}$ & 0.721 & 0.724 & 0.667 & 0.675 & 0.745 & 0.750 \\
\hline AIC & 8773.8 & 8735.0 & 4506.5 & 4455.1 & 4270.1 & 4232.2 \\
\hline
\end{tabular}

Notes: Ethnicity fixed effects and same control variables as those in baseline regressions are included. Due to space limit, they are not reported. Robust standard errors clustered at the province level are in parenthesis. *, $* *$, and $* * *$ indicate significance level at $10 \%, 5 \%$ and $1 \%$, respectively. 
Table 11. The impact of Great Famine on First Generation Cognitive Disability: Disability Survey Data

\begin{tabular}{|c|c|c|c|c|c|c|}
\hline \multicolumn{7}{|c|}{ Dependent Variable: Cognitive Disability (Dummy) } \\
\hline & \multicolumn{2}{|c|}{ All } & \multicolumn{2}{|c|}{ Males } & \multicolumn{2}{|c|}{ Females } \\
\hline & (1) & (2) & (3) & (4) & (5) & (6) \\
\hline \multicolumn{7}{|c|}{ Panel A: All Famine Survivors } \\
\hline Famine* & $0.474^{* * *}$ & $0.544^{* * *}$ & 0.222 & 0.276 & $0.704^{* * *}$ & $0.794^{* * *}$ \\
\hline Born in 1959-1961 & $(0.165)$ & $(0.158)$ & $(0.244)$ & $(0.234)$ & $(0.204)$ & (0.199) \\
\hline \multirow[t]{2}{*}{ Born in 1959-1961 } & 1.952 & 1.166 & 12.330 & 12.363 & -7.442 & -10.037 \\
\hline & $(12.894)$ & $(13.179)$ & $(12.757)$ & $(12.897)$ & $(20.839)$ & $(21.407)$ \\
\hline \multirow[t]{2}{*}{ Famine } & -0.122 & & $-0.335^{*}$ & & 0.078 & \\
\hline & $(0.209)$ & & $(0.163)$ & & $(0.265)$ & \\
\hline \multirow[t]{2}{*}{ Male dummy } & $-9.228^{* * *}$ & $-9.510 * * *$ & & & & \\
\hline & $(2.691)$ & $(2.758)$ & & & & \\
\hline Province dummies & No & Yes & No & Yes & No & Yes \\
\hline Observations & 127578 & 127578 & 62789 & 62789 & 64789 & 64789 \\
\hline Adjusted $\mathrm{R}^{2}$ & 0.003 & 0.003 & 0.002 & 0.003 & 0.003 & 0.004 \\
\hline AIC & 1910907.7 & 1910773.2 & 922770.6 & 922692.4 & 984252.0 & 984178.3 \\
\hline \multicolumn{7}{|c|}{ Panel B: Married Famine Survivors } \\
\hline Famine* & $0.404^{* * *}$ & $0.454^{* * *}$ & 0.006 & 0.021 & $0.744^{* * *}$ & $0.836^{* * *}$ \\
\hline Born in 1959-1961 & $(0.124)$ & $(0.124)$ & $(0.123)$ & $(0.122)$ & $(0.204)$ & $(0.197)$ \\
\hline \multirow[t]{2}{*}{ Born in 1959-1961 } & -0.055 & -0.912 & $16.163^{* *}$ & $16.158^{* *}$ & -14.012 & -16.808 \\
\hline & $(10.856)$ & $(10.968)$ & $(6.560)$ & $(6.480)$ & $(19.442)$ & $(20.125)$ \\
\hline \multirow[t]{2}{*}{ Famine } & -0.004 & & $-0.107^{*}$ & & 0.092 & \\
\hline & $(0.140)$ & & $(0.062)$ & & $(0.238)$ & \\
\hline \multirow[t]{2}{*}{ Male dummy } & $-18.530 * * *$ & $-18.708^{* * *}$ & & & & \\
\hline & $(2.626)$ & $(2.678)$ & & & & \\
\hline Province dummies & No & Yes & No & Yes & No & Yes \\
\hline Observations & 119756 & 119756 & 58318 & 58318 & 61438 & 61438 \\
\hline Adjusted $\mathrm{R}^{2}$ & 0.002 & 0.003 & 0.000 & 0.001 & 0.003 & 0.004 \\
\hline AIC & 1753607.6 & 1753517.1 & 782609.0 & 782559.1 & 931092.0 & 931016.2 \\
\hline
\end{tabular}

Notes: Born in 1959-1961 is a dummy that equals 1 if the person was born during 1959-1961 and equals 0 if the person was born during 1963-1965. The dependent variable is multiplied by 10000 . Age, its square and cubic terms, ethnicity Han dummy, education level, log family income per person are controlled in all the regressions. Due to space limit, they are not reported. Robust standard errors clustered at the province level are in parenthesis. ${ }^{*}, * *$, and ${ }^{* * *}$ indicate significance level at $10 \%, 5 \%$ and $1 \%$, respectively. 
Table 11 (cont.). The impact of Great Famine on First Generation Cognitive Disability: Disability Survey Data

\begin{tabular}{|c|c|c|c|c|c|c|}
\hline \multicolumn{7}{|c|}{ Dependent Variable: Cognitive Disability (Dummy) } \\
\hline & \multicolumn{2}{|c|}{ All } & \multicolumn{2}{|c|}{ Males } & \multicolumn{2}{|c|}{ Females } \\
\hline & (1) & $(2)$ & (3) & (4) & (5) & (6) \\
\hline \multicolumn{7}{|c|}{ Panel C: Married Famine Survivors with Children } \\
\hline Famine* & $0.415^{*}$ & $0.451^{* *}$ & -0.010 & -0.004 & $0.834^{* *}$ & $0.916^{* *}$ \\
\hline Born in 1959-1961 & $(0.204)$ & $(0.197)$ & $(0.145)$ & $(0.142)$ & $(0.398)$ & $(0.380)$ \\
\hline \multirow[t]{2}{*}{ Born in 1959-1961 } & 0.008 & -0.660 & $21.489 * * *$ & $22.001 * * *$ & -19.887 & -23.288 \\
\hline & $(12.790)$ & $(12.961)$ & (7.356) & (7.230) & $(22.287)$ & $(22.996)$ \\
\hline \multirow[t]{2}{*}{ Famine } & -0.018 & & -0.055 & & 0.016 & \\
\hline & $(0.115)$ & & $(0.043)$ & & $(0.213)$ & \\
\hline \multirow[t]{2}{*}{ Male dummy } & $-18.118^{* * *}$ & $-18.367^{* * *}$ & & & & \\
\hline & $(2.603)$ & (2.684) & & & & \\
\hline Province dummies & No & Yes & No & Yes & No & Yes \\
\hline Observations & 103628 & 103628 & 51679 & 51679 & 51949 & 51949 \\
\hline Adjusted $\mathrm{R}^{2}$ & 0.002 & 0.002 & 0.000 & 0.001 & 0.002 & 0.003 \\
\hline AIC & 1511115.6 & 1511051.0 & 687102.3 & 687068.2 & 785664.0 & 785597.4 \\
\hline
\end{tabular}

Notes: Born in 1959-1961 is a dummy that equals 1 if the person was born during 1959-1961 and equals 0 if the person was born during 1963-1965. The dependent variable is multiplied by 10000 . Age, its square and cubic terms, ethnicity Han dummy, education level, log family income per person are controlled in all the regressions. Due to space limit, they are not reported. Robust standard errors clustered at the province level are in parenthesis. *, $* *$, and ${ }^{* *}$ indicate significance level at $10 \%, 5 \%$ and $1 \%$, respectively. 
Table 12. Intergenerational Impact of Famine on Math Scores for the Children of Rural Fathers: CFPS 2010 Sample

\begin{tabular}{|c|c|c|c|c|c|c|}
\hline \multicolumn{7}{|c|}{ Dependent Variable: Math Test Scores (the higher the better) } \\
\hline & \multicolumn{2}{|c|}{ All } & \multicolumn{2}{|c|}{ One Child } & \multicolumn{2}{|c|}{ More than One Child } \\
\hline & (1) & (2) & (3) & (4) & (5) & (6) \\
\hline Boy dummy*Famine* & $0.051 * * *$ & $0.043 * *$ & -0.077 & $-0.125^{*}$ & $0.054 * * *$ & $0.044^{* *}$ \\
\hline Father born in 1959-1961 & $(0.015)$ & $(0.016)$ & $(0.080)$ & $(0.067)$ & $(0.017)$ & $(0.018)$ \\
\hline Famine* & $-0.088 * *$ & $-0.099 * *$ & 0.054 & $0.135 * *$ & $-0.098 * * *$ & $-0.107 * * *$ \\
\hline Father born in 1959-1961 & $(0.036)$ & $(0.038)$ & $(0.083)$ & $(0.057)$ & $(0.034)$ & $(0.034)$ \\
\hline \multirow[t]{2}{*}{ Father born in 1959-1961 } & 0.340 & 0.484 & -0.853 & -1.742 & 0.453 & 0.608 \\
\hline & $(0.744)$ & $(0.764)$ & $(1.672)$ & $(2.144)$ & $(0.793)$ & $(0.841)$ \\
\hline \multirow[t]{2}{*}{ Famine } & 0.010 & & 0.053 & & 0.005 & \\
\hline & $(0.025)$ & & $(0.035)$ & & $(0.030)$ & \\
\hline \multirow[t]{2}{*}{ Boy dummy } & $-1.006 * *$ & $-0.915^{*}$ & -2.163 & -0.678 & -0.802 & -0.750 \\
\hline & $(0.431)$ & $(0.500)$ & $(1.625)$ & $(1.854)$ & $(0.498)$ & $(0.572)$ \\
\hline Other Controls & Yes & Yes & Yes & Yes & Yes & Yes \\
\hline Province dummies & No & Yes & No & Yes & No & Yes \\
\hline Observations & 968 & 968 & 153 & 153 & 815 & 815 \\
\hline Adjusted $R^{2}$ & 0.208 & 0.228 & 0.123 & 0.263 & 0.204 & 0.224 \\
\hline AIC & 5882.9 & 5835.8 & 922.5 & 867.5 & 4979.7 & 4936.4 \\
\hline
\end{tabular}

Notes: Ethnicity fixed effects and same control variables as those in table 3 are included. Due to space limit, they are not reported. Robust standard errors clustered at the province level are in parenthesis. ${ }^{*}, * *$, and ${ }^{* * *}$ indicate significance level at $10 \%, 5 \%$ and $1 \%$, respectively.

Table 13. Intergenerational Impact of Famine on Math Scores for the Children of Rural Fathers: Different Families

\begin{tabular}{|c|c|c|c|c|c|c|}
\hline \multicolumn{7}{|c|}{ Dependent Variable: Math Test Scores (the higher the better) } \\
\hline & \multicolumn{2}{|c|}{ All } & \multicolumn{2}{|c|}{ Boys } & \multicolumn{2}{|c|}{ Girls } \\
\hline & (1) & (2) & (3) & (4) & (5) & (6) \\
\hline Family Type*Famine* & $-0.160 * *$ & $-0.146^{*}$ & 0.020 & 0.043 & $-0.325 * *$ & $-0.343 * * *$ \\
\hline Father born in 1959-1961 & $(0.068)$ & $(0.072)$ & $(0.075)$ & $(0.091)$ & $(0.119)$ & $(0.112)$ \\
\hline Famine* & -0.038 & -0.060 & -0.022 & -0.043 & -0.046 & -0.059 \\
\hline Father born in 1959-1961 & $(0.038)$ & $(0.041)$ & $(0.040)$ & $(0.044)$ & $(0.056)$ & $(0.060)$ \\
\hline \multirow[t]{2}{*}{ Father born in 1959-1961 } & -0.095 & 0.158 & -0.491 & -0.271 & 0.117 & 0.378 \\
\hline & $(0.705)$ & $(0.733)$ & $(0.968)$ & $(1.033)$ & $(1.044)$ & $(1.071)$ \\
\hline \multirow[t]{2}{*}{ Famine } & -0.003 & & 0.019 & & $-0.048^{*}$ & \\
\hline & $(0.027)$ & & $(0.033)$ & & $(0.027)$ & \\
\hline \multirow[t]{2}{*}{ Boy dummy } & $-1.913 * * *$ & $-2.097^{* * *}$ & & & & \\
\hline & $(0.508)$ & $(0.566)$ & & & & \\
\hline Province dummies & No & Yes & No & Yes & No & Yes \\
\hline Observations & 968 & 968 & 547 & 547 & 421 & 421 \\
\hline Adjusted $R^{2}$ & 0.229 & 0.250 & 0.207 & 0.236 & 0.300 & 0.327 \\
\hline AIC & 5841.1 & 5789.3 & 3352.6 & 3307.5 & 2467.0 & 2423.0 \\
\hline
\end{tabular}

Notes: Family type equals 1 if the family has both sons and daughters, and equals 0 otherwise. Its level term and same control variables as those in table 3 are included. Due to space limit, they are not reported. 
Table 14. Son-preference Channel Detection: Add the Interaction Term of Dummy Variable for Ethnicities without Son-preference

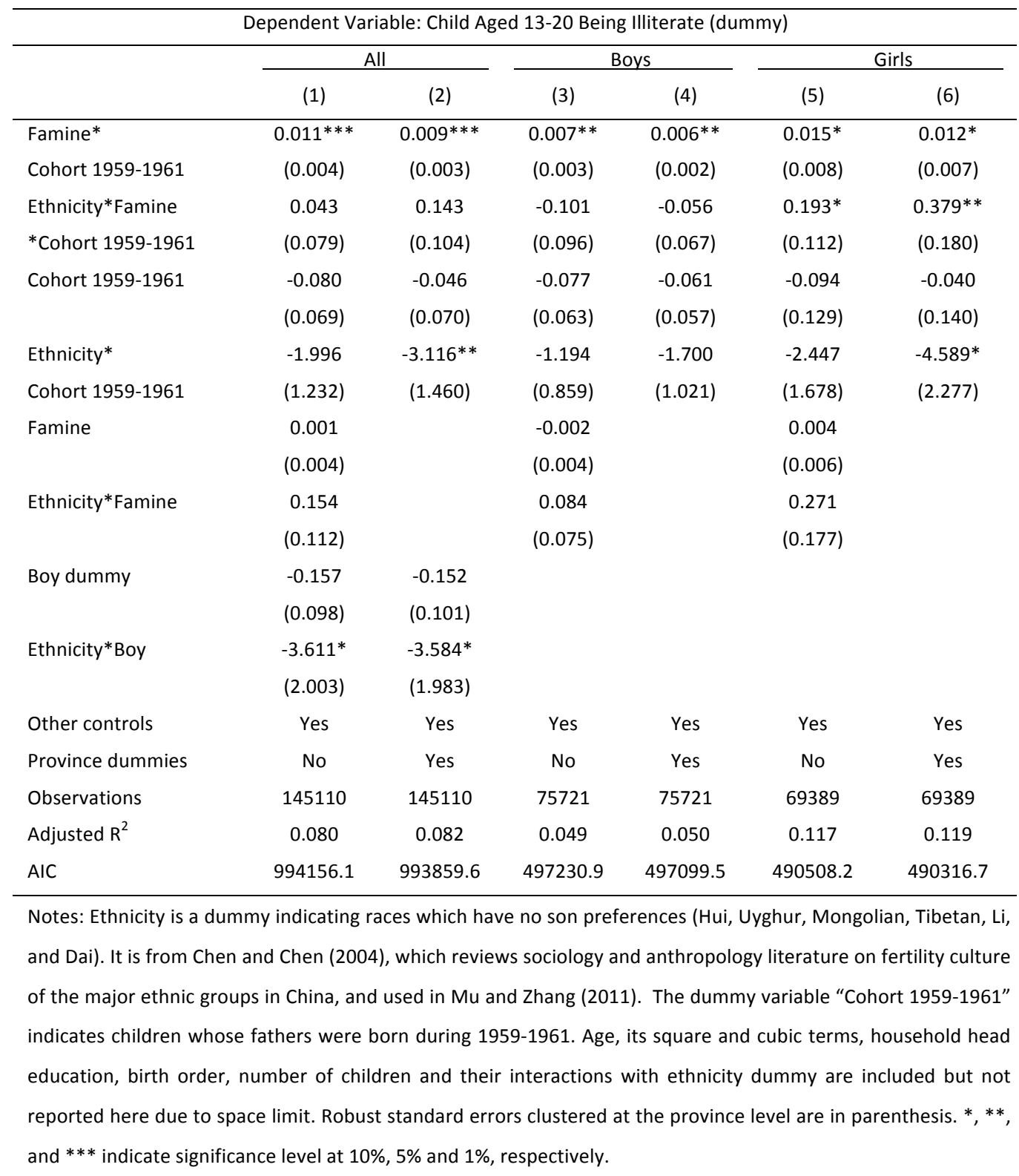


Table A1. The Impact of Fathers' Exposures to Famine in the Early Childhood on Their Children's Illiteracy Rate (Rural Sample from 2000 Census)

\begin{tabular}{|c|c|c|c|c|c|c|}
\hline & \multicolumn{6}{|c|}{ Dependent Variable: Child Aged 13-20 Being Illiterate (dummy) } \\
\hline & \multicolumn{2}{|c|}{ All } & \multicolumn{2}{|c|}{ Boys } & \multicolumn{2}{|c|}{ Girls } \\
\hline & (1) & (2) & (3) & (4) & (5) & (6) \\
\hline Famine* & $0.013^{* *}$ & $0.011^{* * *}$ & $0.007^{*}$ & $0.006^{*}$ & $0.019 * *$ & $0.017^{*}$ \\
\hline Cohort 1959-1961 & $(0.005)$ & $(0.004)$ & $(0.004)$ & $(0.003)$ & (0.009) & $(0.009)$ \\
\hline \multirow[t]{2}{*}{ Cohort 1959-1961 } & -0.119 & -0.097 & -0.107 & -0.095 & -0.135 & -0.108 \\
\hline & $(0.078)$ & $(0.076)$ & $(0.070)$ & $(0.061)$ & $(0.144)$ & $(0.153)$ \\
\hline \multirow[t]{2}{*}{ Famine } & 0.001 & & -0.002 & & 0.005 & \\
\hline & $(0.005)$ & & $(0.004)$ & & $(0.007)$ & \\
\hline \multirow[t]{2}{*}{ Boy dummy } & $-0.213^{*}$ & -0.205 & & & & \\
\hline & $(0.119)$ & $(0.121)$ & & & & \\
\hline \multirow[t]{2}{*}{ Age } & -0.392 & -0.228 & -2.402 & -2.273 & 2.805 & 3.032 \\
\hline & $(4.328)$ & $(4.460)$ & (5.014) & (4.954) & (9.003) & $(9.275)$ \\
\hline \multirow[t]{2}{*}{ Age square } & 0.036 & 0.024 & 0.157 & 0.148 & -0.162 & -0.178 \\
\hline & $(0.289)$ & $(0.298)$ & $(0.330)$ & $(0.326)$ & $(0.594)$ & $(0.611)$ \\
\hline \multirow[t]{2}{*}{ Age cubic } & -0.001 & -0.001 & -0.003 & -0.003 & 0.003 & 0.004 \\
\hline & $(0.006)$ & $(0.007)$ & $(0.007)$ & $(0.007)$ & $(0.013)$ & $(0.013)$ \\
\hline Household head & $-0.833 * * *$ & $-0.802 * * *$ & $-0.574 * * *$ & $-0.551 * * *$ & $-1.096 * * *$ & $-1.053 * * *$ \\
\hline education & $(0.243)$ & $(0.240)$ & $(0.165)$ & $(0.165)$ & $(0.343)$ & $(0.333)$ \\
\hline \multirow[t]{2}{*}{ Number of children } & $0.363 * * *$ & $0.391 * * *$ & $0.383^{* * *}$ & $0.448 * * *$ & $0.365^{* *}$ & $0.373 * *$ \\
\hline & $(0.117)$ & $(0.135)$ & $(0.116)$ & $(0.138)$ & $(0.136)$ & $(0.154)$ \\
\hline \multirow[t]{2}{*}{ Birth order } & -0.028 & -0.030 & -0.064 & -0.064 & -0.002 & -0.004 \\
\hline & $(0.052)$ & $(0.052)$ & $(0.071)$ & $(0.070)$ & $(0.063)$ & $(0.063)$ \\
\hline Province dummies & No & Yes & No & Yes & No & Yes \\
\hline Observations & 145110 & 145110 & 75721 & 75721 & 69389 & 69389 \\
\hline Adjusted $\mathrm{R}^{2}$ & 0.068 & 0.071 & 0.043 & 0.045 & 0.101 & 0.105 \\
\hline AIC & 996045.3 & 995562.7 & 497751.9 & 497569.5 & 491803.8 & 491464.3 \\
\hline
\end{tabular}

Notes: From 1\% sample of China Population Census 2000. Ethnicity fixed effects (55 races dummies) are controlled in all regressions. Due to space limit, they are not reported. The dummy variable "Cohort 1959-1961" indicates children whose fathers were born during 1959-1961. Robust standard errors clustered at the province level are in parenthesis. $*, * *$, and $* * *$ indicate significance level at $10 \%, 5 \%$ and $1 \%$, respectively. 
Table A2. The Intergenerational Impact (Rural Father to Children) of Famine on Word Test Scores (CFPS 2010 Sample)

\begin{tabular}{|c|c|c|c|c|c|c|c|c|c|}
\hline \multicolumn{10}{|c|}{ Dependent Variable: Word Test Scores (the higher the better) } \\
\hline & \multicolumn{6}{|c|}{ Famine Measure at the Provincial Level } & \multicolumn{3}{|c|}{ Famine Measure at the County-Level } \\
\hline & \multicolumn{2}{|c|}{ All } & \multicolumn{2}{|c|}{ Boys } & \multicolumn{2}{|c|}{ Girls } & \multirow{2}{*}{$\frac{\text { All }}{\text { (7) }}$} & \multirow{2}{*}{$\begin{array}{c}\text { Boys } \\
(8)\end{array}$} & \multirow{2}{*}{$\begin{array}{l}\text { Girls } \\
(9)\end{array}$} \\
\hline & (1) & (2) & (3) & (4) & (5) & (6) & & & \\
\hline \multirow[t]{2}{*}{ Famine*Cohort 1959-1961 } & $-0.073^{* *}$ & $-0.084 * *$ & -0.025 & -0.039 & $-0.107^{* *}$ & $-0.098^{*}$ & -4.559 & -1.039 & $-9.142^{*}$ \\
\hline & $(0.034)$ & $(0.036)$ & $(0.050)$ & $(0.060)$ & $(0.044)$ & $(0.052)$ & $(4.683)$ & $(6.097)$ & $(5.279)$ \\
\hline \multirow[t]{2}{*}{ Cohort 1959-1961 } & -0.231 & -0.175 & -1.434 & -1.260 & 0.671 & 0.456 & -0.069 & -1.653 & 1.903 \\
\hline & $(0.936)$ & $(0.982)$ & (1.296) & (1.445) & $(1.132)$ & (1.207) & $(1.457)$ & (1.993) & (1.635) \\
\hline \multirow[t]{2}{*}{ Famine } & 0.025 & & $0.056^{*}$ & & $-0.035^{*}$ & & -0.587 & -0.066 & -1.926 \\
\hline & $(0.024)$ & & $(0.031)$ & & $(0.019)$ & & $(1.534)$ & (1.973) & $(2.254)$ \\
\hline \multirow[t]{2}{*}{ Boy dummy } & $-1.536^{* *}$ & $-1.300 *$ & & & & & $-1.555^{* *}$ & & \\
\hline & $(0.598)$ & $(0.651)$ & & & & & $(0.611)$ & & \\
\hline Other controls & Yes & Yes & Yes & Yes & Yes & Yes & Yes & Yes & Yes \\
\hline Province dummies & No & Yes & No & Yes & No & Yes & No & No & No \\
\hline Observations & 968 & 968 & 547 & 547 & 421 & 421 & 968 & 547 & 421 \\
\hline Adjusted $R^{2}$ & 0.214 & 0.225 & 0.200 & 0.197 & 0.317 & 0.318 & 0.214 & 0.194 & 0.314 \\
\hline AIC & 6347.2 & 6310.4 & 3650.0 & 3624.7 & 2662.2 & 2631.3 & 6349.4 & 3652.6 & 2663.5 \\
\hline
\end{tabular}

Notes: At the provincial level, famine is measured as the difference of the highest mortality during 1959-1961 and average mortality during 1956-1958. At the county level, it is calculated as (Cohort size 1956-1958-cohort size 1959-1961)/cohort size 1956-1958. Ethnicity fixed effects are controlled in all regressions. Due to space limit, they are not reported. Cohort 1959-1961 (dummy) indicates children whose fathers were born during 1959-1961. Other controls same as those in Table 3 are included but not reported here. Robust standard errors clustered at the province level (columns 1-6) or county level (columns $7-9$ ) are in parenthesis. ${ }^{*}, * *$, and ${ }^{* * *}$ indicate significance level at $10 \%, 5 \%$ and $1 \%$, respectively. 
Table A3. Intergenerational Impact of Famine on Short Memory Scores for the Children of Rural Famine Survivors: Baseline Results Based on CFPS 2012

\begin{tabular}{|c|c|c|c|c|c|c|}
\hline \multicolumn{7}{|c|}{ Dependent Variable: Short Term Memory Test Scores (the higher the better) } \\
\hline & \multicolumn{2}{|c|}{ All } & \multicolumn{2}{|c|}{ Boys } & \multicolumn{2}{|c|}{ Girls } \\
\hline & (1) & $(2)$ & (3) & (4) & (5) & (6) \\
\hline \multicolumn{7}{|c|}{ Panel A: Children of Rural Fathers } \\
\hline Famine* & 0.004 & $0.009 * *$ & $0.021 * *$ & $0.024 * *$ & -0.008 & -0.003 \\
\hline Father born in 1959-1961 & $(0.005)$ & $(0.004)$ & $(0.008)$ & $(0.009)$ & $(0.007)$ & $(0.007)$ \\
\hline \multirow[t]{2}{*}{ Father born in 1959-1961 } & -0.013 & -0.087 & -0.289 & -0.279 & 0.161 & 0.009 \\
\hline & $(0.115)$ & (0.099) & $(0.231)$ & $(0.251)$ & (0.209) & $(0.186)$ \\
\hline \multirow[t]{2}{*}{ Famine } & -0.005 & & $-0.015^{*}$ & & 0.002 & \\
\hline & $(0.009)$ & & $(0.008)$ & & $(0.012)$ & \\
\hline \multirow[t]{2}{*}{ Boy dummy } & $-0.291^{*}$ & $-0.215^{* *}$ & & & & \\
\hline & $(0.144)$ & $(0.086)$ & & & & \\
\hline Province dummies & No & Yes & No & Yes & No & Yes \\
\hline Observations & 1083 & 1083 & 528 & 528 & 555 & 555 \\
\hline Adjusted $R^{2}$ & 0.017 & 0.097 & 0.031 & 0.071 & 0.011 & 0.129 \\
\hline AIC & 4228.6 & 4108.4 & 2042.4 & 1990.4 & 2188.6 & 2088.6 \\
\hline \multicolumn{7}{|c|}{ Panel B: Children of Rural Mothers } \\
\hline Famine* & 0.001 & 0.003 & -0.005 & 0.000 & 0.003 & 0.005 \\
\hline Mother born in 1959-1961 & $(0.007)$ & $(0.008)$ & $(0.011)$ & $(0.010)$ & $(0.014)$ & $(0.016)$ \\
\hline \multirow[t]{2}{*}{ Mother born in 1959-1961 } & 0.036 & -0.016 & 0.271 & 0.196 & -0.154 & -0.197 \\
\hline & $(0.146)$ & $(0.145)$ & $(0.249)$ & $(0.256)$ & $(0.201)$ & $(0.213)$ \\
\hline \multirow[t]{2}{*}{ Famine } & 0.001 & & -0.000 & & 0.004 & \\
\hline & $(0.007)$ & & $(0.006)$ & & $(0.010)$ & \\
\hline \multirow[t]{2}{*}{ Boy dummy } & -0.190 & -0.085 & & & & \\
\hline & $(0.189)$ & $(0.175)$ & & & & \\
\hline Province dummies & No & Yes & No & Yes & No & Yes \\
\hline Observations & 1022 & 1022 & 497 & 497 & 525 & 525 \\
\hline Adjusted $R^{2}$ & 0.038 & 0.079 & 0.034 & 0.052 & 0.031 & 0.083 \\
\hline AIC & 3956.8 & 3883.3 & 1911.5 & 1872.9 & 2058.2 & 2002.7 \\
\hline
\end{tabular}

Notes: Ethnicity fixed effects and same control variables as those in table 3 are included. Robust standard errors clustered at the province level are in parenthesis. $*, * *$, and $* * *$ indicate significance level at $10 \%, 5 \%$ and $1 \%$, respectively. 
Table A4. The Intergenerational Impact (Rural Mothers to Children) of Famine on Math and Word Test Scores (CFPS 2010 Sample)

\begin{tabular}{|c|c|c|c|c|c|c|}
\hline & \multicolumn{2}{|c|}{ All } & \multicolumn{2}{|c|}{ Boys } & \multicolumn{2}{|c|}{ Girls } \\
\hline & (1) & $(2)$ & (3) & (4) & (5) & (6) \\
\hline \multicolumn{7}{|c|}{ Panel A: Math Test Scores (the higher the better) } \\
\hline Famine* & 0.011 & 0.007 & 0.006 & 0.003 & -0.014 & -0.010 \\
\hline Cohort 1959-1961 & $(0.023)$ & $(0.020)$ & $(0.035)$ & $(0.032)$ & $(0.027)$ & $(0.035)$ \\
\hline \multirow[t]{2}{*}{ Cohort 1959-1961 } & 0.283 & 0.320 & $1.347^{* *}$ & $1.438^{* *}$ & -0.311 & -0.412 \\
\hline & $(0.438)$ & $(0.509)$ & $(0.603)$ & $(0.645)$ & $(0.687)$ & $(0.877)$ \\
\hline \multirow[t]{2}{*}{ Famine } & -0.001 & & -0.002 & & 0.003 & \\
\hline & $(0.023)$ & & $(0.030)$ & & $(0.019)$ & \\
\hline \multirow[t]{2}{*}{ Boy dummy } & -0.515 & -0.584 & & & & \\
\hline & $(0.476)$ & $(0.494)$ & & & & \\
\hline Province dummies & No & Yes & No & Yes & No & Yes \\
\hline Observations & 939 & 939 & 519 & 519 & 420 & 420 \\
\hline Adjusted $R^{2}$ & 0.203 & 0.235 & 0.184 & 0.216 & 0.304 & 0.322 \\
\hline AIC & 5666.0 & 5599.3 & 3130.5 & 3078.6 & 2507.9 & 2465.6 \\
\hline \multicolumn{7}{|c|}{ Panel B: Word Test Scores (the higher the better) } \\
\hline Famine* & 0.034 & 0.019 & 0.048 & 0.033 & -0.019 & -0.020 \\
\hline Cohort 1959-1961 & $(0.034)$ & $(0.035)$ & $(0.043)$ & $(0.048)$ & $(0.043)$ & $(0.046)$ \\
\hline \multirow[t]{2}{*}{ Cohort 1959-1961 } & -0.363 & -0.034 & -0.662 & 0.023 & 0.939 & 0.848 \\
\hline & $(0.834)$ & $(0.802)$ & $(1.129)$ & $(1.252)$ & $(0.975)$ & (0.898) \\
\hline \multirow[t]{2}{*}{ Famine } & 0.006 & & 0.029 & & -0.024 & \\
\hline & $(0.016)$ & & $(0.024)$ & & $(0.019)$ & \\
\hline \multirow[t]{2}{*}{ Boy dummy } & $-2.037 * *$ & $-1.891 * *$ & & & & \\
\hline & $(0.748)$ & $(0.835)$ & & & & \\
\hline Province dummies & No & Yes & No & Yes & No & Yes \\
\hline Observations & 939 & 939 & 519 & 519 & 420 & 420 \\
\hline Adjusted $R^{2}$ & 0.187 & 0.205 & 0.175 & 0.193 & 0.270 & 0.278 \\
\hline AIC & 6084.5 & 6036.8 & 3361.7 & 3319.2 & 2697.9 & 2664.0 \\
\hline
\end{tabular}

Notes: Ethnicity fixed effects are controlled in all the regressions. Due to space limit, they are not reported. Cohort 1959-1961 (dummy) indicates children whose mother was born during 1959-1961. Other controls same as those in Table 3 are included but not reported here. Robust standard errors clustered at the province level are in parenthesis. ${ }^{*}, * *$, and $* * *$ indicate significance level at $10 \%, 5 \%$ and $1 \%$, respectively. 
Table A5. Intergenerational Impact of Famine on Math Scores: Adding the Age Difference Between Parents

\begin{tabular}{|c|c|c|c|c|c|c|}
\hline & \multicolumn{2}{|c|}{ All } & \multicolumn{2}{|c|}{ Boys } & \multicolumn{2}{|c|}{ Girls } \\
\hline & (1) & $(2)$ & (3) & (4) & (5) & (6) \\
\hline \multicolumn{7}{|c|}{ Panel A: Children of Rural Fathers } \\
\hline Famine* & $-0.056^{*}$ & $-0.073 * *$ & -0.004 & -0.022 & $-0.107^{* *}$ & $-0.119 * *$ \\
\hline Cohort 1959-1961 & $(0.031)$ & $(0.034)$ & $(0.037)$ & $(0.043)$ & $(0.041)$ & $(0.045)$ \\
\hline \multirow[t]{2}{*}{ Cohort 1959-1961 } & 0.237 & 0.470 & -1.146 & -0.914 & 1.603 & 1.893 \\
\hline & $(0.770)$ & (0.799) & $(0.828)$ & $(0.916)$ & $(1.025)$ & $(1.107)$ \\
\hline \multirow[t]{2}{*}{ Famine } & 0.009 & & 0.021 & & -0.020 & \\
\hline & $(0.025)$ & & $(0.031)$ & & $(0.021)$ & \\
\hline \multirow[t]{2}{*}{ Boy dummy } & $-1.098 * *$ & $-1.165 * *$ & & & & \\
\hline & $(0.527)$ & $(0.530)$ & & & & \\
\hline Age difference & 0.035 & -0.003 & 0.073 & 0.007 & -0.002 & 0.016 \\
\hline between parents & $(0.068)$ & $(0.063)$ & $(0.107)$ & $(0.099)$ & $(0.101)$ & $(0.098)$ \\
\hline Province dummies & No & Yes & No & Yes & No & Yes \\
\hline Observations & 957 & 957 & 542 & 542 & 415 & 415 \\
\hline Adjusted $R^{2}$ & 0.212 & 0.233 & 0.223 & 0.251 & 0.252 & 0.263 \\
\hline AIC & 5806.5 & 5759.6 & 3324.6 & 3281.1 & 2469.2 & 2432.9 \\
\hline \multicolumn{7}{|c|}{ Panel B: Children of Rural Mothers } \\
\hline Famine* & 0.014 & 0.007 & 0.014 & 0.002 & -0.020 & -0.017 \\
\hline Cohort 1959-1961 & $(0.026)$ & $(0.022)$ & $(0.037)$ & $(0.033)$ & $(0.028)$ & $(0.036)$ \\
\hline \multirow[t]{2}{*}{ Cohort 1959-1961 } & 0.254 & 0.331 & $1.224^{*}$ & $1.442 * *$ & -0.150 & -0.222 \\
\hline & $(0.468)$ & $(0.514)$ & $(0.629)$ & $(0.648)$ & $(0.705)$ & $(0.873)$ \\
\hline \multirow[t]{2}{*}{ Famine } & -0.003 & & -0.005 & & 0.000 & \\
\hline & $(0.023)$ & & $(0.028)$ & & $(0.018)$ & \\
\hline \multirow[t]{2}{*}{ Boy dummy } & -0.456 & -0.536 & & & & \\
\hline & $(0.489)$ & $(0.504)$ & & & & \\
\hline Age difference & 0.027 & -0.013 & 0.077 & 0.021 & -0.030 & -0.039 \\
\hline between parents & $(0.050)$ & $(0.051)$ & $(0.060)$ & $(0.069)$ & $(0.078)$ & $(0.073)$ \\
\hline Province dummies & No & Yes & No & Yes & No & Yes \\
\hline Observations & 923 & 923 & 511 & 511 & 412 & 412 \\
\hline Adjusted $R^{2}$ & 0.200 & 0.232 & 0.188 & 0.219 & 0.298 & 0.311 \\
\hline AIC & 5561.4 & 5501.9 & 3086.9 & 3035.6 & 2452.6 & 2413.4 \\
\hline
\end{tabular}

Notes: Ethnicity fixed effects are controlled in all the regressions. Due to space limit, they are not reported. Cohort 1959-1961 (dummy) indicates children whose father/mother was born during 1959-1961. Other controls same as those in Table 3 are included but not reported here. Robust standard errors clustered at the province level are in parenthesis. $*, * *$, and $* * *$ indicate significance level at $10 \%, 5 \%$ and $1 \%$, respectively. 
Table A6: Intergenerational Impact of Famine on Math Scores for the Children of Rural Mothers: CFPS 2010 Sample

\begin{tabular}{|c|c|c|c|c|c|c|}
\hline \multicolumn{7}{|c|}{ Dependent Variable: Math Test Scores (the higher the better) } \\
\hline & \multicolumn{2}{|c|}{ All } & \multicolumn{2}{|c|}{ One Child } & \multicolumn{2}{|c|}{ More than One Child } \\
\hline & (1) & $(2)$ & (3) & (4) & (5) & (6) \\
\hline Boy dummy*Famine* & 0.029 & 0.028 & 0.151 & 0.016 & 0.022 & 0.021 \\
\hline Mother born in 1959-1961 & $(0.025)$ & $(0.024)$ & $(0.112)$ & $(0.092)$ & $(0.027)$ & $(0.026)$ \\
\hline Famine* & 0.008 & -0.002 & -0.160 & -0.139 & 0.033 & 0.021 \\
\hline Mother born in 1959-1961 & $(0.026)$ & $(0.026)$ & $(0.116)$ & $(0.095)$ & $(0.024)$ & $(0.025)$ \\
\hline \multirow[t]{2}{*}{ Mother born in 1959-1961 } & -0.325 & -0.115 & 0.910 & $3.269 * * *$ & $-0.690 * *$ & -0.477 \\
\hline & $(0.307)$ & $(0.352)$ & $(1.604)$ & $(1.075)$ & $(0.308)$ & $(0.388)$ \\
\hline \multirow[t]{2}{*}{ Famine } & -0.008 & & -0.003 & & -0.009 & \\
\hline & $(0.012)$ & & $(0.028)$ & & $(0.016)$ & \\
\hline \multirow[t]{2}{*}{ Boy dummy } & $-0.589 * *$ & $-0.512^{*}$ & -1.728 & -1.716 & $-0.591^{*}$ & $-0.566^{*}$ \\
\hline & $(0.276)$ & $(0.288)$ & (1.147) & $(0.997)$ & $(0.308)$ & $(0.316)$ \\
\hline Province dummies & No & Yes & No & Yes & No & Yes \\
\hline Observations & 939 & 939 & 148 & 148 & 791 & 791 \\
\hline Adjusted $R^{2}$ & 0.581 & 0.585 & 0.239 & 0.441 & 0.584 & 0.589 \\
\hline AIC & 5056.2 & 5022.7 & 843.8 & 769.6 & 4280.4 & 4245.7 \\
\hline
\end{tabular}

Notes: Ethnicity fixed effects and same control variables as those in table 3 are included. Due to space limit, they are not reported. Robust standard errors clustered at the province level are in parenthesis. $*, * *$, and $* * *$ indicate significance level at $10 \%, 5 \%$ and $1 \%$, respectively.

Table A7: Intergenerational Impact of Famine on Math Scores for the Children of Rural Mothers: Different Families

\begin{tabular}{|c|c|c|c|c|c|c|}
\hline \multicolumn{7}{|c|}{ Dependent Variable: Math Test Scores (the higher the better) } \\
\hline & \multicolumn{2}{|c|}{ All } & \multicolumn{2}{|c|}{ Boys } & \multicolumn{2}{|c|}{ Girls } \\
\hline & (1) & (2) & (3) & (4) & (5) & (6) \\
\hline Family Type*Famine* & -0.008 & -0.023 & 0.027 & -0.036 & -0.126 & -0.095 \\
\hline Mother born in 1959-1961 & $(0.055)$ & $(0.065)$ & $(0.072)$ & $(0.094)$ & $(0.071)$ & $(0.077)$ \\
\hline Famine* & -0.006 & 0.001 & -0.026 & -0.004 & 0.037 & 0.040 \\
\hline Mother born in 1959-1961 & $(0.037)$ & $(0.040)$ & $(0.047)$ & $(0.053)$ & $(0.029)$ & $(0.033)$ \\
\hline \multirow[t]{2}{*}{ Mother born in 1959-1961 } & -0.296 & -0.486 & 0.876 & 0.556 & $-1.345^{*}$ & -1.371 \\
\hline & $(0.667)$ & $(0.804)$ & $(0.787)$ & $(1.023)$ & $(0.784)$ & (0.911) \\
\hline \multirow[t]{2}{*}{ Famine } & -0.013 & & -0.018 & & -0.012 & \\
\hline & $(0.026)$ & & $(0.033)$ & & $(0.020)$ & \\
\hline \multirow[t]{2}{*}{ Boy dummy } & -0.754 & -0.775 & & & & \\
\hline & $(0.576)$ & $(0.469)$ & & & & \\
\hline Province dummies & No & Yes & No & Yes & No & Yes \\
\hline Observations & 939 & 939 & 519 & 519 & 420 & 420 \\
\hline Adjusted $R^{2}$ & 0.215 & 0.245 & 0.204 & 0.232 & 0.301 & 0.318 \\
\hline AIC & 5630.4 & 5569.4 & 3100.9 & 3052.5 & 2495.1 & 2452.7 \\
\hline
\end{tabular}

Notes: Family type equals 1 if the family has both sons and daughters, and equals 0 otherwise. Its level term and same control variables as those in table 3 are included. Due to space limit, they are not reported. Robust standard errors clustered at the province level are in parenthesis. ${ }^{* * *}$, and ${ }^{* *}$ indicate significance level at $10 \%, 5 \%$ and $1 \%$, respectively. 